\title{
EL DELITO DE SOLICITACIÓN EN EL SANTO OFICIO DE LIMA*
}

POR

\author{
René Millar Carvacho \\ Academia Chilena de la Historia
}

\section{RESUMEN}

Después de reseñar la política oficial sobre el delito de solicitación y las órdenes que emanan del Consejo de la Suprema Inquisición, el autor analiza este tema en el tribunal inquisitorial de Lima a lo largo de toda su existencia.

\section{Abstract}

The delict of «solicitación» in the «Santo Oficio» of Lima.

After annalyzing the official policy on the delict of «solicitacion» and the laws promulgated by the Council of the «Suprema Inquisicionn, the author foctises in the Inquisitorial Tribunal of Lima through his whole existence.

\section{INTRODUCCIÓN}

La Inquisición española nació con el objeto de combatir a los judaizantes y con el correr del tiempo fue ampliando su jurisdicción sobre otras manifestaciones heréticas, pero también comenzó a conocer de ciertos hechos o dichos que no constituían herejías. Esto ocurrió porque al Santo Oficio le preocupaba que las ideas heréticas pudieran penetrar en la península, al amparo de ciertas corrientes ambiguas, de creencias erróneas o de prácticas censurables desde el

* Este artículo se basa en una ponencia presentada al seminario "La Inquisición en Hispanoamérica", organizado por la Universidad del Museo Socjal Argentino, en Buenos Aires, los dras 11 y 12 de septiembre de 1995. 
punto de vista católico. Por eso la Inquisición perseguirá, entre otros, a los blasfemos, a las hechiceras, a los bígamos y también a los solicitantes.

Nosotros trataremos de estudiar la forma como el Tribunal de Lima reprimió este delito. Al respecto nos interesa destacar en primer lugar las fuentes de que hemos dispuesto para efectuar este trabajo, indicando sus limitaciones y valores. A continuación, después de una somera descripción sobre la evolución histórica del sacramento de la penitencia, nos centramos en el análisis de la política de la Santa Sede respecto de este delito, que se explicita en las diversas bulas que dicta sobre la materia. Más adelante, describimos el procedimiento que se estableció por el Consejo de la Suprema para reprimir el delito y cerramos ese apartado con el estudio de la práctica que en dicho campo siguió el Tribunal de Lima. Luego, nos adentramos al estudio de la actividad inquisitorial, es decir de las características que revistió la represión del delito que nos interesa, intentando efectuar algunas cuantificaciones y comparaciones con la situación que se da en los tribunales peninsulares. En ese mismo apartado trataremos de precisar algunos elementos genéricos de los solicitantes y de sus víctimas, para tratar de aproximarnos a los tipos humanos que se ven involucrados en esos hechos. Culmina nuestro trabajo, con un análisis tentativo acerca de los factores que habrían llevado a determinados sacerdotes a cometer este delito, al mismo tiempo que buscamos una explicación razonable para un hecho interesante: el éxito que muchos alcanzan en su relación con las solicitadas.

Para nosotros la solicitación está asociada a una administración del sacramento de la penitencia que ponía mucho énfasis en los pecados contra el sexto y el noveno mandamiento y sobre todo a la existencia de un numeroso contingente de miembros del clero que carecían de vocación y de formación religiosa. Algunos sacerdotes con esas características, incapaces de dominar sus pasiones, encontraron en América un amplio campo entre las miles de indígenas, que se transformaron en presa fácil para aquellos clérigos que estaban dispuestos a abusar de su poder y prestigio.

\section{LAS FUENTES}

Para estudiar la actividad inquisitorial del Tribunal de Lima existe una gran limitación en materia de fuentes, debido a la pérdida de la mayoría de los expedientes originales de los procesos de fe. Lo cierto es que buena parte del archivo del Santo Oficio peruano se extravió, en el transcurso de los años, después de su abolición en 1820. Para mala fortuna de los investigadores, el grueso de la documentación perdida corresponde a los expedientes de las cau-

Missionalia Hispanica

Hispania Sacra 48 (1996) 
sas de fe, de los cuales se conservan poco más de una decena, todos en Madrid, en el Archivo Histórico Nacional. La presencia de algunas causas originales en la península obedece a razones que tenían que ver con el modo de proceder de la Inquisición española. Esta era gobernada por el Inquisidor General y el Consejo de la Suprema, que, entre otras labores, tenía la obligación de vigilar el funcionamiento de los tribunales de distrito, tanto en el ámbito administrativo como procesal. Pues bien, cuando el Consejo, a la vista de la información proveniente de aquéllos, consideraba que el procedimiento seguido en la substanciación de una determinada causa no se había ajustado a derecho, podía solicitar al tribunal el envío del expediente completo. En consecuencia, los originales limeños existentes en la actualidad en la sección Inquisición del Archivo Histórico Nacional de Madrid, corresponden a causas de fe cuya tramitación generó diversas dificultades, que llevaron al Consejo a pedir el envío de toda la documentación. El carácter excepcional de ese procedimiento explica el escaso número de procesos que se conservan en aquel repositorio. Además, la mayoría se refieren a encausados por hechos y dichos considerados manifiestamente heréticos y condenados a relajación. La solicitación no era un delito que tuviera aquella connotación y por lo mismo sólo hemos podido disponer de un expediente íntegro sobre la materia.

No obstante lo anterior, es posible estudiar, con bastantes limitaciones, algunos aspectos de la actividad del Tribunal de Lima en materias de fe, merced a las denominadas relaciones de causas. Estas eran unos resúmenes de todos los procesos, que los tribunales de distrito tenían la obligación de enviar sistemáticamente al Consejo. A través de ellas, cuidaba del funcionamiento de los tribunales en el ámbito procesal'. Y en la medida que se enviaban con regularidad, constituyen verdaderas series, que en el caso del Tribunal de $\mathrm{Li}$ ma se extienden desde su establecimiento en 1570 hasta mediados del siglo XVIII. Sin embargo, las correspondientes al período $1700-1750$ no se archivaron con el resto, quedando dispersas en diversos legajos, to que facilitó la pérdida de muchas de ellas ${ }^{2}$. Su extensión varía entre una y cinco páginas y contienen los principales datos biográficos del procesado, una síntesis de las testificaciones y de las respuestas del encausado a las acusaciones, para terminar con la sentencia.

\footnotetext{
1 René Millar Carvacho, "Aspectos del procedimiento inquisitorial en la Inquisición de Lima". En Homenaje a Alfonso Garcia Gallo. Universidad Complutense, Madrid, 1995.

${ }^{2}$ El envio de relaciones durante el siglo XVIII por parte de la Inquisición peruana constituye una excepción, puesto que los tribunales peninsulares no continuaron con esa práctica por decisión del Consejo, que reemplazó esa forma de control por otra. Esta modificación es posible que sea la responsable de la dispersión que experimentaron las que siguieron llegando de ultramar.
} 
El valor de estas relaciones como fuente estadística es considerable, como ha quedado demostrado en diversas investigaciones realizadas en centros universitarios europeos. Pero también, ante la inexistencia de otra documentación, pueden ser muy útiles para acercarse al conocimiento más específico de la actividad inquisitorial; en otras palabras, para estudiar determinados delitos o ciertos comportamientos de algunos grupos o sectores de la sociedad. Es evidente que, para ese tipo de trabajos, presentan bastantes debilidades, por tratarse de síntesis de gruesos expedientes. Obviamente, en ellas no están recogidas de manera textual las declaraciones de los involucrados, ya fuesen testigos o encausados. Los hechos nos llegan a través de un doble tamiz; primero, el del secretario que toma nota de las declaraciones y, en segundo término, el del funcionario que efectúa el resumen de la causa. Este último, que es el más importante, podría significar una alteración profunda de los dichos del declarante. Sin embargo, hay que considerar que, por lo general, era la misma persona la que efectuaba ambas labores, con lo cual disminuía la posibilidad de alteraciones mayores. Además, los Inquisidores revisaban las relaciones antes de enviarlas al Consejo, acompañadas muchas veces de una pequeña nota explicativa. En consecuencia, pensamos que las relaciones reflejan bien algunos de los aspectos más significativos del proceso, sin que existan alteraciones fundamentales del expediente ${ }^{3}$.

El problema mayor no está en la tergiversación, sino en la información que no entregan, en la que omiten por los requerimientos del resumen. Eso no tiene remedio y debe asumirse, pero también hay que valorar los datos que esa documentación nos proporciona. Entre ellos está la identificación del reo, con su nombre, edad, actividad, lugar de nacimiento y de residencia; el delito del que se le acusa; casi siempre una apretada síntesis de las testificaciones, junto a información básica de los testigos; también, hay noticias sobre las audiencias otorgadas al reo y la respuesta a la acusación; siempre culmina la relación con "el voto en definitiva" del Tribunal, que determina la sentencia. Buena parte de esa información corresponde a datos específicos, no factibles de ser alterados por interpretación del escribiente. Lo que puede merecer algún reparo son los resúmenes de las declaraciones; pero como casi siempre se limitan a indicar los hechos y expresiones más sustanciales del proceso, considerando la doble vertiente del testigo y del acusado, la posible deformación del funcionario no debiera ser significativa.

3 Por lo demís, asi pudimos comprobarlo de hecho al comparar el expediente completo de ta causa de Rafael Venegas con su correspondiente relación.

Missionalia Hispanica

Hispania Sacra 48 (1996) 


\section{EL SACRAMENTO DE LA CONFESIÓN}

La confesión privada, tal como se efectúa en la actualidad, no siempre se ha practicado en la Iglesia católica. Aún más, hasta el siglo VII, al parecer, predominó la denominada confesión pública, que no implicaba necesariamente, como podría suponerse, una declaración de los pecados ante otros fieles. Aquel nombre se debe a que buena parte de su liturgia tenía un carácter público, es decir, al penitente se le imponían una serie de penitencias públicas (y también privadas), como privación de la comunión eclesiástica, ayunos, limitaciones en el ejercicio de cargos, limosnas, etc. y sólo después de cumplir con ellas era reconciliado. Se aplicaba a quienes habían pecado públicamente y por ello debían reparar el escándalo de manera también pública, con lo cual, los fieles se enteraban de que el pecador se había confesado de sus pecados ${ }^{4}$. Esto significa que la confesión se reservaba sólo a los que estaban en pecado mortal.

La penitencia privada habría comenzado a practicarse desde el siglo VI, a raíz de la participación del pueblo en los ritos penitenciales de la cuaresma. Primitivamente, en ellos participaban sólo los penitentes, que, vestidos de sacos, descalzos y de bruces en el suelo, a las puertas de la iglesia, eran penitenciados en una solemne ceremonia. Poco a poco a estos oficios también se fueron incorporando no penitentes, hasta que llegó a ser común la integración de todo el pueblo. Al iniciarse la cuaresma, los sacerdotes citaban a los fieles a confesarse, estuviesen o no en pecado mortal ${ }^{5}$. Un elemento distintivo importante de la confesión privada fue su carácter secreto, que inicialmente se circunscribe a los pecados también secretos, que quedaban bajo la jurisdicción del presbítero. Los pecados públicos, en cambio, eran objeto de la confesión pública, que aplicaba el obispo. Con el paso del tiempo se fueron dictando disposiciones para garantizar el carácter secreto de la confesión, como el Decreto de Graciano, que conminaba al sacerdote a mantener el sigilo so pena de ser destituido. Otras diferencias importantes entre ambos tipos de confesión se produjeron en torno a la frecuencia de su aplicación y a la duración de la penitencia. La confesión pública se efectuaba sólo de vez en cuando, en cambio la privada pudo reiterarse con cierta periodicidad. En la primera, algunos pecados, como la apostasía, el adulterio y el homicidio, se consideraban de tal

${ }^{4}$ Esa situación hacía que todos los fieles se enteraran de los pecados del penitente, sin necesidad de confesarlos de viva voz ante ellos. JOSÉ M. GONZALEZ DEL VALLE, El sacramiento de la penirencia. Fundamentos históricos de su regulación actual. EUNASA, Pamplona, 1972, pp. 204.

s JoSÉ M. GONZÁLEZ DEL VALLE, op. cit., pp. 164-I65. El tema referente a los tipos de confesión y a la evolución en el tiempo es muy discutido y no existe consenso entre los diferentes autores. En todo caso, en lo que sí hay acuerdo es en que la confesión privada y secreta, como se practica en cl presente no se practicó siempre așí. 
gravedad, que la penitencia duraba toda la vida del pecador ${ }^{6}$. La privada, por el contrario, fue tendiendo a perdonar todos los pecados al momento de la confesión. Al parecer, ambas formas de penitencia habrían coexistido hasta los siglos XII y XII'?

Un hito importante en la evolución del sacramento de la penitencia corresponde al IV Concilio de Letrán de 1215, que en el Canon 21 estableció la obligatoriedad de la confesión anual. Parece claro, que ese precepto no implica una ruptura con la doctrina y regulación del sacramento, pues ya en el siglo XII todos los teólogos se pronunciaban a favor de la confesión obligatoria y en muchas diócesis, ya desde el siglo IX, se practicaba la confesión anual como preparatoria a la comunión pascual ${ }^{8}$. Sin embargo, como señala Jean Delameau, al imponerse ese deber a todos los fieles, generalizando su práctica, se modificó de manera definitiva "la vida religiosa y psicológica", la mentalidad, de los católicos y de buena parte de occidente ${ }^{9}$. En ese Canon, además de establecerse la obligatoriedad de la confesión, se insistió en el carácter secreto de la misma, instruyendo al sacerdote para que mantuviese el sigilo; a éste también se le advertía para que obtuviera del penitente la declaración de todos sus pecados, junto con las circunstancias que los rodeaban y que permitían determinar la mayor o menor malicia que en ellos había ${ }^{10}$.

La obligatoriedad de la confesión anual y la indagación de las circunstancias que acompañaban a los pecados, influirá en la publicación, desde el siglo XIII, de numerosas sumas casuistas sobre el sacramento y en la multiplicación de los manuales de confesores. El objeto de las sumas era ayudar a los confesores a enfrentar la gran diversidad de casos que se presentaban, para lo cual se les indicaba cómo interrogar al penitente, cómo aclarar los móviles y las circunstancias y valorar la gravedad de la falta, y cómo superar los obstáculos que dificultaban una buena confesión. Los manuales, escritos por lo general en romance, con una orientación más pastoral, estaban en su mayor parte destinados al uso ya sea de sacerdotes o de fieles y tenían un fin didáctico, pues pretendían enseñar cómo administrar y cómo recibir el sacramento de la penitencia" . Todas estas obras tienden a precisar, a veces con una gran minuciosidad, los más variados casos y tipos de faltas en que podían caer los fieles. De hecho fueron instrumentos que se entregaron a los sacerdotes para aplicar

\footnotetext{
6 PIERRE ADNÈS, S. I. La penitencia. BAC, Madrid, 1981, p. 86 y 93-105.

$?$ lbid, p. 143.

\& Dictionnaire du théologie catholique. París, 1911.

9 Jean Delumeau, La confesión y el perdón. Alianza editorial, Madrid, 1992, p. 15.

10 ADELINA SARRIÓN MORA, Sexualidad y confesion. La solicitación ante el Tribunal del Santo Oficio (sigles XVI-XIX). Alianza Editorial, Madrid, 1994, p. 22.

"JEAN DELUMEAU, Le péché et la peur. La culpabilisction en Occident (XII-XVIII siècles). Fayard, Paris, 1983, pp. 222-226.
}

Missionalia Hispanica

Hispania Sacra 48 (1996) 
la confesión de una cierta manera, que implicaba una indagación a fondo, minuciosa, de la vida íntima de los fieles. En definitiva, a raíz del Canon 21 y de los manuales y sumas que se publicaron para llevar sus disposiciones a la práctica, la confesión adquirió un carácter masivo y su administración llevó al sacerdote a inquirir por los aspectos más recónditos de la vida y conciencia de los fieles.

El otro hito importante en la evolución de la penitencia corresponde al Concilio de Trento, que, a causa de su cuestionamiento por los protestantes, precisó de manera definitiva su doctrina y reguló su práctica. En la medida que aquellos consideraron que los sacramentos no transmitían por sí mismo la gracia santificante, se les reducía a un mero instrumento útil, en cuanto confirmaban que Dios era quien había dado la fe a los hombres. Según Lutero, debía tenerse fe en la gracia y misericordia de Dios, que había prometido salvar al pecador, sin considerar los esfuerzos que éste pudiera realizar. Específicamente con respecto a la penitencia, al sostener que no ha sido instituida por Dios sino por la Iglesia, termina por negarle su carácter de sacramento y por desconocer que fuese necesaria para el perdón de los pecados. Sin embargo, acepta que en ciertos casos puede ser útil para corrección de los pecadores, aunque cualquier cristiano estaba en condiciones de administrarla, puesto que la absolución consistiría en recordarles a aquéllos la misericordia de Dios y que sus pecados les serían perdonados por tener $\mathrm{fe}^{\mathrm{i2}}$.

El Concilio, en vista de esas tesis, reafirmó a los sacramentos como eficaces en sí mismo, al transmitirnos la gracia santificante; ninguno de los siete que se confirman, es ineficaz ni superfluo, aunque no todos son iguales, ni tampoco necesarios para la totalidad de los fieles. Tres de ellos, bautismo, confirmación y orden sagrado, confieren carácter y por eso no pueden reiterarse. Sólo a los ministros corresponde administrarlos, por lo que es herético sostener que cualquier creyente puede hacerlo. En cuanto a la penitencia propiamente tal, se establece en materia doctrinaria que es un sacramento instituido por Cristo para permitir la reconciliación con Dios después de los pecados cometidos con posterioridad al bautismo, del que es sustancialmente distinto. También se declara que para una perfęcta remisión de los pecados no basta con tener fe en el Evangelio o con temer a Dios, como sostienen los protestantes; además se requieren tres actos, la contrición, la confesión y la satisfacción, que serían las partes constitutivas de la penitencia. La contrición consiste en detestar el pecado cometido con el propósito de no volver a cometerlo. La confesión, que constituye la segunda parte de la penitencia, es la

12 PIERRE ADNĖ, op. cit., pp. 169-172. 
acusación de los pecados con el objeto de que les sean perdonados. La satisfacción es el pago que se hace a Dios por los pecados cometidos.

Respecto a la regulación práctica de la confesión, el Concilio insistió en el carácter judicial que tenía el acto, reservando la función de juez de manera exclusiva a los sacerdotes y obispos; estos últimos, además del papa, podían reservarse la absolución de los pecados más graves. Al mismo tiempo se reafirmó que la confesión debía efectuarse en forma auricular y secreta, una vez al año obligatoriamente, desde el momento que se tiene uso de razón. Y en ella debían decirse en detalle todos los pecados y sus circunstancias, para que el juez pudiese apreciar la mayor o menor malicia de ellos.

\section{LA REGULACIÓN PONTIFICIA Y LA JURISDICCIÓN INQUISITORIAL}

La solicitación es el requerimiento que, con motivo de la confesión, hace un sacerdote a un penitente para efectuar acciones deshonestas. Este delito, durante la Edad Media, al igual que todos los que afectaban a la continencia del clero, era conocido por los tribunales eclesiásticos ordinarios. Sin embargo, a raíz de la Reforma Protestante, el papa entregará su encausamiento a los tribunales inquisitoriales de España. Una petición al papa Pablo IV del arzobispo de Granada Pedro Guerrero, de destacada actuación en el Concilio Trento, estuvo en el origen de esa determinación. Probablemente, una rencilla local de la Compañía de Jesús con otras órdenes religiosas, unido a la especial preocupación del arzobispo por la moralidad del clero motivaron aquella petición. Lo cierto es que el 18 de febrero de 1559 , el prelado obtuvo una bula de Pablo IV que entregaba el conocimiento de ese delito a la Inquisición de Granada ${ }^{13}$.

Ante una nueva demanda del arzobispo Guerrero, el papa Pío IV, el 16 de abril de 1561 publicó una bula, por medio de la cual, en los reinos de España, sometía el encausamiento del delito de solicitación a los tribunales de Inquisición. Así, en virtud de ella, cualquier clérigo que cometiera tal delito, sin importar su dignidad, orden, condición, tipo, grado o preeminencia, quedaba sometido a la jurisdicción del Santo Oficio. Se fundamentaba tal determinación en la existencia en dichos reinos de muchos sacerdotes que usaban mal del sacramento de la penitencia "atrayendo y provocando a las mujeres para actos deshonestos", con lo que, en vez de reconciliarlas, las "cargaban" con

13 Adeluna Sarrión MORA, op. cit., pp. 59-60.

Missionalia Hispanica

Hispania Sacra 48 (1996) 
más pecados, ofendiendo a la Majestad Divina y provocando gran escándalo entre los fieles ${ }^{14}$.

El argumento de fondo para justificar el cambio de jurisdicción, que le entregaba el conocimiento a un tribunal que enjuiciaba a los que cometían el delito de herejía, se centraba en la pérdida de respeto y el mal uso que aquellos clérigos hacían de uno de los sacramentos instituidos por Cristo. En la medida que los protestantes habían negado el carácter de sacramento a la penitencia, se presumía que quien no la respetaba era porque coincidía con aquel predicamento y cabía su juzgamiento como hereje o por lo menos como sospechoso de herejía. Por otra parte, la rigurosidad con que procedía el Santo Oficio, unida a su compleja red administrativa, eran a esas alturas ampliamente conocidas y por lo tanto se suponía que podría ser más eficaz que los tribunales episcopales para combatir unas conductas desviadas.

Con todo, en los años siguientes, las órdenes religiosas trataron de obtener de la Santa Sede autorización para que los superiores conocieran del delito de solicitación cometido por sus miembros. De hecho, los jesuitas lograron obtener un privilegio al respecto. Esto a su vez generó la reacción del Inquisidor General y el Consejo de la Suprema, que, a través del monarca, presionaron para que la Santa Sede revocara esas excepciones ${ }^{15}$. Tales gestiones tuvieron éxito y el 3 de diciembre de 1592, el papa Clemente VIII declaró que el Santo Oficio de España "podía y debía proceder privativamente" contra los clérigos solicitantes, fueran seculares o regulares ${ }^{16}$.

Otra precisión importante en relación con este delito efectuó la Santa Sede a comienzos del siglo XVII. Hacia 1580, el Tribunal de Lima a raíz de un caso concreto, hizo una consulta a la Suprema con respecto al procedimiento a seguir cuando en el acto de la confesión se solicitaba a una persona a cometer el pecado nefando. El Tribunal no tenía claro si le correspondía seguir la causa debido a que ese pecado y delito estaba expresamente excluido de la jurisdicción inquisitorial, salvo en los tribunales del reino de Aragón, y por otra parte la bula de Pío IV contra los solicitantes sólo se refería a los que requerían mujeres. Ante esa situación, el Consejo de la Suprema, por carta acordada de 9 de diciembre de 1583, le señaló que en ese "negocio se puede y debe conocer en el Santo Oficio"17. Esa determinación de la Inquisición española fue confirmada por el pontífice, que el 24 de noviembre de 1612 expidió un decreto en virtud del cual las solicitaciones en confesión efectuadas a hombres

14 El texto de la bula en su versiones en latín, con la traducción efectuada por la lnquisición, en Archivo Nacional de Chile (ANCh), sección lnquisición, vol. 499, f. 18 y ss.

15.5 ADELINA SARRIón MORA, op. cil., pp. 63-64.

16 Archivo Histórico Nacionnl de Madrid (AHN), sección Códices, libro 9-B, f. 115.

17 ANCh, Inquisicion, vol. 486, f. 135. 
debían merecer el mismo tratamiento que se les daba a las causas que involucraban a mujeres. Esta disposición fue dada a conocer a los tribunales provinciales por carta acordada de la Suprema de 8 de mayo de 1613, que fue recibjda en la Inquisición de Lima el 11 de abril de $1616^{18}$.

Pareciera que la experiencia acumulada en el tratamiento de este delito por la Inquisición de España, hizo que la Santa Sede decidiera regular con mayor precisión el procedimiento a seguir en este tipo de causas. Para ello, el 30 de agosto de 1622, el papa Gregorio XV dictó una nueva bula sobre el particular, que tendrá una gran trascendencia por fijar algunas pautas básicas en materia procesal y penal, que regirán definitivamente. Uno de los aspectos esenciales que se estableció en ella, fue el entregar el conocimiento de esas causas a todos los tribunales inquisitoriales existentes en la cristiandad y no sólo a la de España. A ello se agregaron regulaciones procesales, como las que precisaban las circunstancias que permitían considerar que el delito se había perpetrado. $\mathrm{Al}$ respecto, la praxis inquisitorial había dejado en evidencia que muchos encausados alegaban en su defensa que nunca habían solicitado, porque los dichos o hechos deshonestos Ios había realizado fuera del momento de la confesión. Para poner término a ese subterfugio, que generaba dudas en los tribunales, la bula determinó que debía considerarse como solicitación toda provocación para deshonestidades que se hiciese "en el acto de la confesión sacramental, antes o después del, inmediatamente con ocasión o pretexto de confesión, aunque tal confesión nunca se haya hecho"; e incluso aunque no hubiera confesión, lo mismo acontecía si los hechos ocurrían en el confesonario o en cualquier otro lugar donde se efectuaran confesiones o si se simulaba la realización de ella ${ }^{19}$. En materia procesal, también para permitir el encausamiento de estos delincuentes, se disminuían los requisitos en cuanto a los tipos de testigos y características de las testificaciones. Con el mismo objeto debía instruirse a los confesores para que, bajo apercibimiento de no hacerlo, advirtieran a los penitentes que tenían la obligación de denunciar a los solicitantes. Por último, en dicha bula, se fijaban las penas que debían imponerse a los que cometían este delito.

Con todo, esa bula generó algunas competencias con los obispos debido a que entregaba la jurisdicción sobre el delito a todos los inquisidores y ordinarios de la cristiandad, "a cada uno en sus diócesis y territorios", sin mayor

\footnotetext{
18 ANCh, Inquisición, vol. 499, f. 29.

19 ANCh, Inquisición, vol. 499, f. 18. Al parecer, con anterioridad a esa bula, el 10 de julio de 1614, la Sagrada Cogregación había dictado un decreto que establecía que en las solicitaciones efectuadas en lugares destinados a la confesión, aunque se produjeran fuera de la confesión, procediera el Santo Oficio. Ver JUAN ANTONIO ALEjANDRE, El veneno de Dios. La Inquisición de Sevilla ante el delito de solicitación en confesión. Siglo XXI editores. Madrid, 1995, p. 32.
} 
especificación. Al tenor de ella hubo obispos que iniciaron procesos contra solicitantes, lo cual, a su vez, hizo que la Inquisición recurriera ante la Santa Sede para que reafirmara su jurisdicción privativa. Esa demanda tuvo éxito en 1623, en que aquélla emitió un decreto indicando que el breve de su santidad, en lo referente a los obispos, sólo era aplicable en las provincias donde no había Inquisición ${ }^{20}$. Copias de ese documento fueron enviadas por la Suprema al Tribunal de Lima, con carta de 19 de mayo de 1629 , en que le indicaban que las pusieran en la Cámara del Secreto para servirse de ellas en las ocasiones que se presentaran; además, a los inquisidores les ordenaban que rechazaran las pretensiones sobre jurisdicción copulativa de los obispos, inhibiéndolos cuando lo intentaren, dando cuenta de ello al Consejo. La carta fue recibida por el Tribunal el 8 de enero de 1630 y contestada el 14 de mayo del mismo año 21 .

El proceso de regulación pontificia de la solicitación se cierra con la bula Sacramentum penitentiae del papa Benedicto XIV de 1 de junio de 1741. En ésta se reiteran las disposiciones de la bula de 1622 , como por ejemplo, las que precisaban las situaciones de tiempo y lugar que permitían considerar que el delito se había perpetrado. Pero también se agregan nuevas reglamentaciones, entre las que se destaca aquella que prohibe a los sacerdotes dar la absolución a sus cómplices en el delito de solicitación. Con ello se pretendía evitar la impunidad de muchos delincuentes, que, al perdonar el pecado cometido con el penitente solicitado, lograban que éste no fuera donde otro sacerdote en busca de remisión, con lo que el hecho punible quedaba, muchas veces, sin ser denunciado. Otro aspecto importante que se contempló en la nueva bula, que hasta cierto punto podría indicar un cambio en la política mantenida sobre el delito, corresponde a la imposición de graves censuras a aquellos que hiciesen falsas denuncias de solicitación ${ }^{22}$. Obviamente, se trataba de impedir que las denuncias pudieran ser usadas para perjudicar a determinados clérigos. Sin embargo, era muy sabido por los edictos de fe que a los falsos testigos en ese ámbito se les enjuiciaba por la Inquisición, la que les imponía severas penas. ¿Porqué entonces una ampliación de las censuras? Además, hay que considerar que la Santa Sede, desde el siglo XVI había tratado de fomentar las denuncias en este delito, incluso disminuyendo las restricciones a los testigos y a las testificaciones. Ahora, al amenazar con grave excomunión, que sólo el Pontífice podía absolver, era de prever un retraimiento de los testigos, que con cierta frecuencia eran acusados por los eclesiásticos de enemistad y falso testimonio.

\footnotetext{
20 AdElina SARRIón MORA, op. cit., p. 66

2) ANCh, Inquisición, vol, 488, f. 142.

22 ANCh, Inquisición, vol. 499, f. 27.
} 


\section{EL PROCEDIMIENTO}

a) Las pautas generales

Como consecuencia de la bula de Pío IV de 1561, en los tribunales inquisitoriales comenzaron a seguirse causas contra solicitantes. Pero, como en su tramitación se plantearon algunas dudas, el Consejo de la Suprema expidió un decreto sobre el particular el 15 de julio de 1562, en el que daba instrucciones sobre el modo como debía procederse en ellas. Al respecto se señalaba que habiendo "testificaciones concluyentes" se ordenara la captura del denunciado, "con todo recatamiento y secreto" y se procediera en su causa hasta concluirla. También se ordenaba que, mientras duraba el proceso, los frailes permanecieran en un monasterio que le indicaren, con prohibición de salir, confesar, predicar y de tener voto activo y pasivo. En el caso de los clérigos, debía señalárseles algún lugar de carcẹlería que no fuese aquel en el que cometieron los delitos, además de prohibírseles confesar y predicar. En definitiva, en ese decreto se comenzaba a diseñar un procedimiento especial para estos casos, pues los encausados serían recluidos en lugares particulares, en vez de permanecer durante todo el proceso en las cárceles secretas del Tribunal, como acontecía con los demás reos. La tendencia a darle un tratamiento especial a este delito también se manifiesta en la orden que se da en ese mismo decreto para que no se publicara en los edictos de $\mathrm{fe}^{23}$. Con esto último se trataba de evitar el escándalo y desprestigio del clero, que se produciría de dar a conocer a la comunidad que existían sacerdotes que realizaban esas acciones.

Pocos años después, el Consejo de la Suprema, ante reiteradas consultas de los tribunales, debió precisar algunos aspectos del decreto anterior y de la bula pontificia. Por carta acordada de 20 de diciembre de 1568 , instruía a los tribunales para que, en primer lugar y a causa de una frase ambigua del decreto, a futuro continuaran procediendo en todos los casos de este tipo; en segundo lugar, para que consideraran como solicitación todo requerimiento que se hiciese inmediatamente antes o después de la confesión o con pretexto de ella o en los lugares destinados a ese efecto; el Consejo estimaba que ése era la interpretación correcta de la bula papal, porque de no ser así ocurrirían numerosos "fraudes", como había quedado en evidencia en muchos casos de confesores que replicaban, antes las amenazas de castigo inquisitorial, "que aquello se entendía tratando en la confesión y no fuera de ella"24. Cabe hacer notar que esa orden es el antecedente de la bula papal de 1622, lo que viene a mostrar un determinado estilo de gobierno de la Inquisición española, que consistía en

23 ANCh, Inquisición, vol. 499, f. 21 .

${ }_{24}$ ANCh, Inquisición, vol. 499, f. 21.

Missionalia Hispanica

Hispania Sacra 48 (1996) 
buscar una confirmación de la Santa Sede a las determinaciones ya tomadas sobre aspectos importantes relacionados con las causas de $\mathrm{fe}^{25}$. Otra aclaración de la carta acordada en cuestión, se refería a las sanciones que se establecían mientras duraba la tramitación del proceso, sobre las cuales se insiste en que deben imponerse a todos igual y de manera uniforme.

Todas estas disposiciones se dictaron antes que se estableciera el Tribunal de Lima en el año 1570, aunque una vez que esto aconteció los textos de ellas se le hicieron llegar para que las cumpliese. A poco de establecido, el 7 de noviembre de 1570 el Consejo le instruía, entre otras materias, sobre la no publicación del delito de solicitación en los edictos de fe y sobre la admisión en esas causas sólo de consultores eclesiásticos, a la vez que le ordenaban que en la sustanciación de ellas procedieran con el mayor "secreto y consideración"26.

El Consejo, a medida que acumulaba experiencia en este delito, fue dictando diversas disposiciones que tendieron a aumentar la eficacia de los tribunales en su represión y a configurar un modo de proceder particular dada la especial significación que revestía. Por carta de 2 de marzo de 1576, el Consejo hacía presente a los tribunales su preocupación por la gran cantidad de testificaciones contra solicitantes que se acumulaban en los tribunales y quedaban sin procesarse debido a que estaban concentrados en otros delitos y a que muchas correspondían a declaraciones de un sólo testigo. Para obviar esos inconvenientes se ordenaba la prosecución de dichas causas aunque no contaran más que con un testigo y que además el delito se publicara en los edictos de fe, según un modelo que se enviaba ${ }^{27}$; esta segunda parte implicaba una modificación con respecto a la política inicial sobre la materia. Además, en esa oportunidad, los tribunales fueron advertidos que debían consultar a la Suprema después de revisar las informaciones contra los solicitantes, sin proseguir la causa hasta que aquella lo ordenara. Con todo, al año siguiente, en cartas acordadas de 26 de abril y 14 de septiembre, recibidas en Lima el 15 de abril de 1578, se le mandaba obviar ese trámite, en consideración a los argumentos esgrimidos por los inquisidores de ese tribunal ${ }^{28}$. También, en la primera de esas cartas se les indicaba que en tales causas procedieran conforme a

\footnotetext{
25. Como hemos visto, una situación simitar ocurrió en 1612 con las solicitaciones a los hombres.

26 ANCh, Inquisición, vol. 486, f. $7 v$.

27 Jbid., f. 68 .

28 Ibid, f. 79. La carta acordada de 14 de septiembre de 1577 dice: "cuanto a las dificultades que representais se podrían ofrecer de remitir al Consejo los procesos de los confesores que in acm confesionis solicitan a sus hijas de penitencia, consultado con el Rvdo. Señor Inquisidor General ha parecido conozcais vosotros en ese Santo Oficio de las dichas causas conforme a la Instrucción que con carta acordada de 26 de abril de cste año se despacho sin envinar los procesos al Consejo".
} 
unas instrucciones específicas, firmadas por Pablo García, y que se hacían llegar junto con aquella ${ }^{29}$.

Esas instrucciones fechadas en Madrid a 19 de abril de 1577, correspondían a la regulación procesal más completa que se había dictado en relación con este delito. De hecho, ellas implicaban la configuración definitiva de un procedimiento especial, que en varios aspectos se alejaba de las pautas generales. Así, establecían que antes de ordenarse la captura de uno de esos delincuentes debía poseerse la información de a lo menos dos testigos fidedignos, de cuyas declaraciones se concluya la solicitación en el acto de la confesión o próximamente a ella, antes o después. Además, para orientarse acerca de la confiabilidad de los testigos mujeres, debía preguntarse a "personas graves", con todo recato y sin dejar testimonio escrito, acerca de si las susodichas eran "deshonestas o apasionadas" y de los demás defectos que podían tener. Esos antecedentes debían considerarse por los jueces al momento de decretar la prisión del denunciado y en el resto del proceso. Con respecto a los testigos hay que recordar que por carta acordada de 1576 , es decir del año anterior a estas instrucciones, reafirmada por la bula pontificia de 1622 , se permitía seguir causa a estos delincuentes aunque se contara con uno solo de aquéllos.

En relación con las etapas siguientes del proceso, las instrucciones advertían que la captura de los reos debía ser votada por los inquisidores, en conjunto con el ordinario y consultores eclesiásticos; y que, dependiendo de la calidad de las personas y circunstancias del delito, se dejaba al arbitrio del tribunal el recluirlos en las cárceles secretas o detenerlos en sus casas o monasterios o en otros Iugares que les parecieran más convenientes, conminándolos a mantener el secreto y a no comentar su situación con nadie. Además se indicaba que en estas causas debía procederse como si fuesen de fe, por lo cual debían examinarlos "acerca de la intención y creencia que tuvieron del sacramento de la penitencia cuando cometieron los tales delitos". Si llegaran a reconocer que tuvieron "error en el entendimiento y pertinacia en la voluntad", se les debían secuestrar los bienes como a herejes, cogiéndoles los papeles, libros y escritos que tuvieren. Esto último no podía efectuarse antes de que el reo hubiese confesado tal delito, lo que, de concretarse, implicaba su previa detención en las cárceles secretas.

La votación en definitiva, que importa el término del proceso, requería de la participación del ordinario y consultores, además de los inquisidores. Y se advertía que esos reos no podían ser condenados a penitencia pública, fuese auto de fe $\mathbf{u}$ otra forma. Las sentencias que dictaren debían pronunciarse y notificarse a los reos en la secretaria del Santo Oficio, en presencia de los

29 ANCh, Inquisición, vol. 499, f. 22.

Missionalia Hispanica

Hispania Sacra 48 (1996) 
prelados de los conventos y monasterios y sus compañeros confesores y de los curas o rectores de la ciudad de Lima. En cuanto a las sanciones que debían imponérseles, se indican algunas que no pueden omitirse y otras que se dejan al arbitrio del tribunal. Las infaltables e inmutables eran la abjuración de levi (retractarse de la sospecha leve de herejía en que habían incurrido) y la privación perpetua de administrar el sacramento de la penitencia. Las variables, correspondían a la posibilidad de ser privados de predicar y de administrar otros sacramentos, a las alternativas en cuanto a tiempo y lugar de reclusión y a la duración del destierro que debía imponérseles de los lugares donde habían cometido los delitos.

Además, en relación con ese mismo aspecto, se indicaba que los religiosos podían ser sancionados con disciplinas, a aplicárseles en los capítulos de sus monasterios, después de volver a leerles sus sentencias por un notario del secreto, en presencia de la comunidad; de ser muy grave la culpa, podía dárseles una disciplina en la sala del tribunal, en presencia de los religiosos y clérigos que allí asistieren, amén de condenarlos a "otras penitencias", tales como sus. pensión o privación de sus órdenes y de voz activa y pasiva y de hacer que ocupen el último lugar en el coro y en el refectorio; también podían ser sancionados a cumplir penitencias de culpa grave, disciplinas y oraciones, todo en consideración a la calidad y gravedad de los delitos y demás circunstancias. En cuanto a los clérigos, además de las penas generales de destierro y reclusión, podían aplicárseles las de privación o suspensión de oficio y beneficio, sanciones pecuniarias, disciplinas secretas, ayunos y oraciones ${ }^{30}$.

Culminaban dichas instrucciones con una recomendación a los inquisidores para que en este tipo de causas procediesen "con mucho tiento y consideración". Sin duda, este era uno de los objetivos más importantes que se perseguía con esas normas especiales. A la Inquisición no le interesaba en lo absoluto que la comunidad de los fieles se enterara de los hechos delictivos, para evitar el desprestigio del clero y el consiguiente menoscabo de la religión. Pero, al mismo tiempo tenía una particular preocupación por extirpar el delito, para lo cual la rigurosidad de la sanción y la publicidad de la misma en el ámbito de sus compañeros eclesiásticos, eran estimados los medios más idóneos. La severidad de las penas hay que verlas en función del delito; no se trataba de una herejía, sino de la sospecha de ella, lo que hacía improcedente jurídicamente una condena a abjuración de vehementi o una relajación. Las sanciones que se les imponían eran muy gravosas para los eclesiásticos, pues, aparte de la humillación y restricciones a la libertad, en el caso de los clérigos estaba la pérdida de los beneficios, con lo que quedaban en una situaciốn ma-

3n Ibid., f. 23. 
terial muy precaria; a los religiosos, no se les planteaba el problema de la subsistencia, pero quedaban relegados a una condición de parias al interior de los conventos y ello sin considerar que algunas órdenes, motu proprio, expulsaban a los miembros solicitantes ${ }^{31}$.

Con posterioridad a esas instrucciones, la Suprema, de vez en cuando, a través de cartas acordadas, dictó algunas normas para regular aspectos puntuales del procedimiento a seguir en este delito. Así, como hemos señalado en el apartado sobre la reglamentación pontificia, en 1583, la Suprema, ante una consulta del Tribunal, le instruyó para que procediese con los solicitantes de hombres de la misma forma que en el caso de las mujeres, lo cual fue confirmado con posterioridad por la Santa Sede. Varios años después, en 1625, la Suprema le hizo llegar al Tribunal las primeras de una serie de cartas acordadas sobre los lugares de confesión. En ellas, fechadas el 17 de septiembre y el 22 de octubre, se daban instrucciones a los tribunales para que prohibieran las confesiones en las celdas y capillas secretas de los conventos, y en las casas de los clérigos seculares; los únicos lugares que se autorizaban para efectuarlas eran el cuerpo de la Iglesia, los confesionarios públicos y las sacristías. Por la segunda de las dichas cartas acordadas se aclaró que podían hacerse confesiones en los claustros y capillas existentes en los conventos y también en sus sacristías, siempre que las puertas estuvieran de par en par ${ }^{32}$. Esas disposiciones fueron reiteradas el 12 de octubre de 1675 y dadas a conocer por el Tribunal de Lima a los superiores de los conventos el enero de 1679.

En vista que las causas dejaban en evidencia el escaso cumplimiento de esas instrucciones, la Suprema las volvió a reiterar el 15 de abril de 1692. Con todo, llevada por su afán de limitar al máximo las circunstancias que favorecían la perpetración de este delito, el 16 de noviembre de 1709 dispuso, además de las regulaciones anteriores, que en las iglesias donde hubiere confesonario de "madera con rejilla" todos los penitentes se confesaran por ellos, al mismo tiempo que prohibía las confesiones en los bancos y sillas. También ordenaba que, donde no hubieran confesonarios, se hicieran o a lo menos se confeccionaran "unos canceles con rejilla", que separen al confesor del confesante. Ambos deberían estar sentados de uno y otro lado, sin permitirse, bajo pretexto alguno, que estuviesen juntos, "pues siendo tan fácil y poco costoso el cancel para la referida separación, se podrán poner en esos casos todos los necesarios". Al mismo tiempo, se instruía al Tribunal para que previniera a los confesores que "escusen conversaciones con penitentes antes y después de la confesión" ${ }^{13}$. El 28 de mayo de 1712, la Suprema ordenó al Tribunal que se

\footnotetext{
31 Ver apartado sobre la praxis procesal.

32 ANCh, Inquisición, vol. 395, f'. 100.

3 ANCh, Inquisición, vol. 395, t. 222-224.
} 
volviera a publicar lo dispuesto en la carta acordada anterior, con un agregado que mandaba eliminar los confesonarios con rejillas a la iglesia que existían en los claustros de los conventos. Además, le insistía en la obligación de publicar esas instrucciones en la forma de edicto, fijándolo en todas las iglesias del distrito inquisitorial. El 26 de septiembre de 1729, la Suprema volvió a reiterar, ahora por última vez, aquellas disposiciones ${ }^{34}$.

El Inquisidor General y el Consejo de la Suprema, por carta acordada de 12 de enero de 1708, especificaron la pena de privación de confesar que de acuerdo a las instrucciones de 1577 debía imponerse a los solicitantes. Como en ellas se establecía, sin mayores especificaciones, que debían ser privados perpetuamente de confesar, en muchas causas se imponía esa pena sólo en lo referente a las mujeres, permitiéndoles la administración de ese sacramento a los hombres. Para evitar el descrédito de los mismos confesores y para atenerse al espíritu de la bula de Gregorio XV, se dispuso que en todas las causas futuras de ese tipo, en que correspondiera aplicar la pena de "privación de confesar, sea perpetua y comprensiva igualmente de hombres y mujeres" ${ }^{35}$.

En 1713, la Suprema expidió otras dos cartas acordadas sobre este delito, en un afán por eliminar los resquicios que hacían posible que muchas solicitaciones quedaran sin sanción. La primera es de 17 de junio y con ella se pretendía que los confesores, al enterarse de una solicitación a través de la penitencia, instaran a las víctimas a cumplir con la obligación de denunciar lo acontecido al Santo Oficio, negándoles la absolución mientras no lo hiciesen. Para hacer efectiva esa norma, cuyo incumplimiento implicaba encubrir al delincuente, se instruía al Tribunal para que preguntasen a las mujeres solicitadas si los sacerdotes con los que se confesaron después les comunicaron de aquella obligación; y de no haberlo hecho "se les preguntará por los nombres de los confesores, si eran seculares o regulares y de qué religión, cuanto tiempo ha que las confesaron y en que parte y lugar y lo que pasó y les aconsejaron sobre este punto", después de lo cual, si los antecedentes lo ameritan, levantarán información, aunque antes de proceder y ejecutar remitirán los antecedentes al Consejo ${ }^{36}$.

La segunda carta acordada, expedida el 25 de noviembre, tenía por finalidad combatir la opinión bastante difundida con respecto a que la mujer que consentía en la solicitación no tenía obligación de denunciarla. Tal objetivo pretendió alcanzarse obligando a la publicación de un edicto sobre la materia en todas las iglesias del distrito del Tribunal; también, advirtiendo a los obispos para que instruyeran a los confesores y "mandando que a las mujeres so-

34 Jbid., f. 227. AHN, Inquisición, lib. 1024, f. 262.

3. AHN, Inquisición, lib. 498, f. 249.

36. AHN, Inquisicición, lib, 499, f. 1016. 
licitadas no se les pregunte, ni escriba, aunque voluntariamente lo quieran decir, nada que pueda perjudicarlas; como ni tampoco a los solicitantes...si dijeren o quisieren decir alguna cosa contra ellas", por parecerles que de esa manera disminuyen "la culpa de la solicitación, que es la que únicamente les constituye reos del Santo Oficio ${ }^{+37}$. Esta parte final de la orden de la Suprema resumía el ámbito de interés de la Inquisición con respecto a estos reos. Ellos eran pacientes de dicho tribunal sólo en razón de la solicitación, por lo que todo aquello que no tuviese relación directa con ese hecho era irrelevante para la causa y para la institución encargada de reprimirlo. La carta acordada en cuestión se envió al Tribunal en 1715 y este publicó el edicto correspondiente en la catedral de Lima el 5 de septiembre de $1717^{38}$.

\section{b) La praxis limeña}

Aunque el Tribunal de Lima dispondrá en estas causas de alguna facultad excepcional con respecto al procedimiento general (como la de proceder contra un reo sin esperar la confirmación de la Suprema), lo cierto es que en ese ámbito procesal regularmente debió atenerse a las pautas comunes a los tribunales peninsulares.

El proceso se iniciaba por la denuncia que se hacía ante un comisario del Tribunal. Lo más frecuente era que la víctima denunciara al solicitante. Sin embargo, no resultaba fácil para muchas mujeres dar ese paso, sobre todo si habían consentido en la solicitación. Esta reticencia trató de contrarrestarse informando a los fieles de la obligación que tenían de denunciar ante el Santo Oficio los casos de que tuviesen noticias. Para ello se publicaban edictos de fe, tanto generales como especiales. En los primeros, que eran publicados cada año durante la cuaresma, se indicaban todos los delitos que los fieles debían denunciar, incluyendo el de solicitación, y los segundos se referían a un solo delito, como la bigamia, la hechicería o el que estamos analizando. EI Tribunal de Lima publicó en 1630 un edicto especial sobre esta materia como consecuencia de ciertos requerimientos efectuados por la Suprema al respecto, a través de cartas de 22 de agosto de 1628 y 19 de mayo de 1629 , recibidas en Lima el 18 de enero de 1630. En ambas se pedía información sobre la forma como el Tribunal estaba dando cumplimiento a la bula de Gregorio XV ${ }^{39}$. En

\footnotetext{
37 AHN, Inquisicion, lib. 500, f. 138.

38 AHN, Inquisición, leg. 2199, exp. 5.

39 ANCh, lnquisición, vol 488 , fs. 119 y 142 . Ver el apartado sobre la regulación pontificia. José Toribio Medina, en su Historia del Tribunal de la Lnquisición de Lima (Santiago, 1956, t.II, p. 412), atribuye la publicación de ese edicto al aumento de los casos, sobre todo en Tucumán. Sin embargo, esa afirmación no tiene mayor base, pues la gran actividad del Tribunal en torno a este delito, que 
dicho edicto, se exhortaba a los fieles a que denunciaran, ante los inquisidores - comisarios, bajo pena de excomunión mayor latae sententiae, a los "confesores, clérigos o religiosos... de cualquier orden, grado, preeminencia o dignidad..., que por obra o de palabra hayan solicitado, provocado o intentado, o intentaren solicitar y provocar cualesquiera personas, hombres o mujeres, para actos torpes y deshonestos, que entre sí mismos se hayan de cometer, en cualquier manera, o para que sean terceros o terceras personas de otras personas, o tuvieren con ellos o ellas pláticas y conversaciones de amores ilícitos y deshonestos en el acto de la confesión sacramental, o próximamente a ella, antes o después, o con ocasión y pretexto de la confesión, o sin el dicho pretexto, fuera de la confesión, en los confesionarios o cualquier otro lugar en que se oigan confesiones o este diputado o señalado para ellas..." 40 .

También, las víctimas se veían obligadas a denunciar a los delincuentes luego que otro sacerdote en el acto de la confesión, al enterarse de lo sucedido, le negaba la absolución hasta que nó hubiese concurrido ante el Santo Oficio. Difícilmente una persona podía negarse a cumplir un mandamiento de esa naturaleza, puesto que, a aparte de la presión en el ámbito de su conciencia, tenía la ya comentada obligación de confesarse una vez al año, comprobable mediante una cédula que se le entregaba a todos los que habían recibido el sacramento. De no hacerlo, podía ser excomulgado y su nombre colocado en una tablilla en la puerta de la parroquia ${ }^{4}$. Los sacerdotes estaban instruidos sobre aquel procedimiento por los obispos y superiores de las órdenes religiosas, y además sabían que la Inquisición podía proceder contra ellos si no actuaban de acuerdo con las instrucciones.

En algunas oportunidades el proceso se inicia por una denuncia espontánea del solicitante, que, ya sea por razones de conciencia o por tener noticias de que iba a ser denunciado, se adelantaba a sus acusadores para tratar de obtener un trato más benigno de parte del Tribunal. Con todo, en lo que respecta al Tribunal de Lima el número de estos casos es muy bajo, al punto de representar menos del 7 por ciento de las causas sobre las que tenemos información. Por lo tanto, la gran mayoría de los procesos se originaron en denuncias de las víctimas. Pero, para que el Tribunal decidiera seguirle causa a un sacerdote normalmente esperará a que se junten a lo menos dos denuncias, aunque de

incluye la represión en Tucumán, se cierra a comienzos del siglo XVII, por lo que hacia I630 habłan pasado más de 20 años sin que existiese una preocupación especial de los inquisidores al respecto.

40 José TORIBIo MedinA, Historia del Tribunal de la Inquisición de Lima. Fondo histótico y Bibliografico J.T. Medina. Santiago, 1956, t. II, pp. 412-416.

41 AHN, Inquisición, lib. 1027, f.30. En la relación de una causa seguida en 1571 contra Diego de Arenas se hace referencia a la cédula de confesión que le habría pedido el cura y a la amenaza de que scría excomulgado y su nombre colocado en la tablilla correspondiente de la Iglesia. Ver nota 136. 
hecho, sobre todo después de 1580, procederá después de tener 3 ó 4 de ellas. Sólo hemos detectado una causa, seguida hasta la definitiva, con sentencia condenatoria, sustentada en un único testigo. Ella corresponde a Fray Pedro de Aguirre, de la orden de Santo Domingo, que fue procesado en $1576^{42}$. Lo cierto es que la tendencia que primó claramente en el Tribunal fue la de suspender las causas que tenían un sólo testigo.

Una vez examinadas las denuncias en el Tribunal por los Inquisidores, el representante del ordinario y dos consultores eclesiásticos, se votaba la prosecución de la causa de estimarse que habían méritos suficientes para ello, se ordenaba la prisión del reo y se le conminaba a presentarse ante el Tribunal ${ }^{43}$. Cuando esto último ocurría era normalmente puesto en tas cárceles secretas del Tribunal y de manera excepcional, contraviniendo las instrucciones al respecto, se le recluáa en la celda de algún convento de Lima ${ }^{44}$. La permanencia en las cárceles secretas se extendía, a veces hasta el término de la primera audiencia, pero con mayor frecuencia hasta el inicio de la fase plenaria, cuando el pleito se sometía a prueba. En ambos casos, al reo se daba un convento por cárcel, con orden de mantener absoluto secreto sobre su causa y con prohibición de confesar y administrar otros sacramentos e incluso de decir misa. En relación con los testigos, los comisarios debían informar al Tribunal acerca de su honestidad y forma de vida y, de acuerdo con esto, dar su parecer en cuanto a la credibilidad de la testificación. Esto se anotaba al margen de la declaración de cada testigo. Pero además, el comisario tenía que informar acerca "de la opinión y crédito en que estaba el confesor"45.

42 AHN, Inquisición, lib. 1032, f. $17 \mathrm{v}$.

4.3 Esta es una práctica especial que utiliza el Tribunal, con autorización de la Suprema y no sólo válida para este delito. Consistía en iniciar el proceso, en toda causa que no hubiere manifiesta herejía ni bastante información, ordent́ndole a los reos que comparecieran por sí mismos ante el Tribunal, sin proceder a la captura de ellos. La autorización expedida por la Suprema el 20 de diciembre de 1579 se otorgó ante la expresa petición de los inquisidores de Lima, que hicicron presente los inconvenientes y dificultades que se producían para "prender a los delincuentes por la distancia que haly de unos lugares a otros". ANCh, Inquisicion, vol. 486, f.i4.

${ }^{44}$ Esto último aconteció en la causa de Rafnel Venegas, de la Compañía de Jesús, a quien en 1653 se le señaló por prisión una celda del convento de la orden en Lima, lo cual mereció una censura de parte de la Suprema. ANCh, Inquisición, vol, 49], f. I30. Con anteriorídnd a esa causa, hemos detectado varias otras en que al reo se le asigna la celda de un convento por cárccl, como por ejemplo, las de Fray Felipe de Santa Cruz, de la orden de la Merced, procesado en 1584; de Fray Antonio Ruiz, de la orden de San Francisco, procesado en 1587; la de Fray Diego de Chaves, de la orden de la merced, procesado en 1597; y la de Fray Francisco de Riofrío, también de la Merced, procesado en 1597. AHN, Inquisición, lib. 1027, f. 621; 1ib. 1028, fs. 108, 429, 53 1 y 558.

4. Instructión y orden que comunmente han de guardar los Comisarios y Notarios del Santo Oficio de la Inquisición del Perú. Recopiladas por Miguel Román de Aulestra. Lima, 1796, quinta impresión, p. 9.

Missionalia Hispanica

Hispania Sacra 48 (1996) 
En las audiencias, se interrogaba al reo acerca de sus antecedentes genealógicos, de su la formación intelectual y de los hechos más significativos de su vida, para concentrarse finalmente en la acusación de que era objeto. Todos los interrogatorios a que era sometido el reo en las diversas audiencias estaban orientados a tratar de obtener su confesión, para lo cual constantemente se le amonestaba a que recorriera su memoria, examinara su conciencia y señalara voluntariamente todo lo que hubiese dicho o hecho contra la religión. Cumplida esa etapa, hubiese el reo confesado o no el delito, el fiscal procedía a formalizar la acusación. En este tipo de causas, al sacerdote se le acusaba de solicitante en los confesonarios, sospechoso en la fe, sacrílego, perjuro, y falso y diminuto confitente, esto último siempre que hubiese negado parcialmente las acusaciones. El fiscal, al fundamentar esos cargos, señalaba que el reo "sentía mal" del sacramento de la penitencia al no respetar la "pureza y santidad" con que debía administrarse, y tomarlo como tapadera de sus "torpezas". También, hacía presente que tales hechos iban en detrimento de la religión pues daban argumentos a los herejes y turbaban y escandalizaban a muchas personas, que en vez de recibir la gracia del sacramento eran tentadas a cometer mayores pecados. Continuaba la acusación con una reseña minuciosa de todos los hechos y dichos de los que era acusado, de la que se omitían los datos que individualizaban al testigo ${ }^{46}$.

En la fase plenaria, en la que debían presentarse las pruebas, se efectuaba la ratificación de testigos, que se hacía ante el comisario que había recibido la denuncia, ahora acompañado de las denominadas "personas honestas", es decir de unos funcionarios inquisitoriales que servían de ministros de fe. Esta etapa, por lo general, duraba bastante tiempo debido a las dificultades que imponían las distancias $y$, por lo mismo, ocurría con cierta frecuencia que algunos testigos no eran encontrados para su ratificación o costaba mucho tiempo ubicarlos. La movilidad que caracterizaría a un alto porcentaje de la población de estos territorios sería, a juicio de los Inquisidores de Lima, una de las razones que dilataban las ratificaciones ${ }^{47}$. Por otra parte, en las solicitaciones de zonas apartadas, como Tucumán, Chile, Paraguay o Quito, podían pasar varios años entre la denuncia y la ratificación, a tal punto que no era extraño que algunos testigos hubiesen fallecido. Así, en la causa de Fray Juan de Medina, franciscano, residente en Chile, la primera denuncia se efectuó el

46 Una amplia, aunque no completa, transcripción de una acusación fiscal en causa de solicitación, se encuentra en la obra de José Toribio Medina, Historia del Tribunal del Santo Oficio de la Inquisición en Chile. Fondo Histórico y Bibliografico J.T. MEDINA. Santiago, 1952, pp. 448-457.

47 En una nota incluida en las relaciones de causas de 1592 , los lnquisidores señalaban al Consejo: "La dilación de ios negocios es aquí forzosa más que en otra parte porque como toda gente de acá es de paso el testigo que se examina en una parte cuando se busca para ratificar suele estar quinientas leguns y a veces mil de donde se examinó". AHN, Inquisición, lib. 1028, f. 192 
3 de abril de 1578 y las ratificaciones se ordenaron en 1597, concretándose sólo una de las tres testificaciones originales, por muerte de una testigo e imposibilidad de ubicar a la otra ${ }^{48}$. En Tucumán, donde era frecuente que pasaran dos o tres años, e incluso más, entre la denuncia y la ratificación, una cantidad significativa de testigos no era habido, sobre todo en el caso de las mujeres indias, a causa de su fallecimiento. Ya José Toribio Medina, en su historia sobre la Inquisición en las provincias del Plata, reparaba en este fenómeno ${ }^{49}$, que afectaba a muchas indígenas jóvenes o de mediana edad. No obstante, ese problema, la mayoría de las causas llegaba a término, porque por lo general el número de testigos era muy elevado, superando la decena y en algunos casos el medio centenar, hasta llegar una causa, de modo excepcional, a tener 90 testificaciones ${ }^{50}$. En contadas oportunidades, el reo fue absuelto de la instancia debido a que no se dispuso de a lo menos la ratificación de dos testigos mayores de edad ${ }^{51}$.

Para su defensa, los reos podían asesorarse por abogados, que debían elegir de la nómina que tenía el Tribunal para esos efectos. En estas causas, los "abogados de presos" eran eclesiásticos, con experiencia en materia de derecho canónico. A mediados del siglo XVII se desempeñaban como tales en las causas de solicitación de este tribunal los eclesiásticos Alvaro de Ibarra, catedrático de prima de leyes de la Universidad de San Marcos, y Alonso Coronado, catedrático de víspera de cánones de la misma Universidad. De las relaciones de causas se desprende que los solicitantes, en su defensa, a veces interponían tachas a los testigos de la acusación. En algunos casos alegaban que las declaraciones en su contra eran efectuadas por mujeres de "mal vivir",

48 AHN, Inquisición, lib. 1028 fs. 532 y 543 . En esta causa, a pesar de tenerse solo una ratificación, se siguió hasta la definitiva, condenándose el reo a las penas habituales, debido a que confesó su delito.

49 José Toribio Medina, El Tribunal del santo Oficio de la Inquisición de las Provincias del Plata. Imprenta Elzeviriana. Santiago, 1899, p. 125.

50 En la causa de Fray Diego Chaves, mercedario, residente en la provincia de Tucumán y procesado en 1597, se ratificaron 90 testigos; los inquisidores dijeron de él "que como no fuese vieja o fea que a todas las (indias) había solicitado y que a muchas de ellas había conocido carnalmente". (AHN, Inquisición, lib. 1028 , fs. 531 v; 558 y 593). En la causa de Fray Alonso Díaz Vizarro, franciscano, residente en la provincia de Tucumán, testificaron 27 personas (AHN, lnquisición, lib. I028, fs. 531 v y 559). En la causa de Francisco de Rioftío, ya citada, 7 testigos no se ratificaron por haber fallecido. El mercedario de la provincia de Tucumán, Alonso Diaz, tuvo $4 \mathrm{I}$ testificaciones de mujeres indins, de las cuales se ratificaron 20 , otras 20 habían fallecido y una no fue ubicada (AHN, Inquisicion, lib. 1028 , fs. 557 v y 595). Andrés Corral, franciscano, residente en la Villa de las Juntas, Tucumán, fue testificado por 31 mujeres indias, de las cuales 16 se ratificaron y 6 fallecieron antes (AHN, Inquisición, lib. 1029, f. 79)

3! Causas de Miguel Jeronimo Caro (1603) y Francisco Guillen Chaparro (1604). AHN, Inquisición, lib. 1029 , fs. 138; 333 y 335 .

Missionałia Hispanica

Hispania Sacra 48 (1996) 
rameras, gente vil, de poca capacidad, y que por lo tanto no merecían crédito ${ }^{52}$.

En relación con la tacha de testigos, el argumento que más se esgrime tiene que ver con la capacidad y fiabilidad de los indígenas. El Tribunal, en una primera etapa, no reconoció validez jurídica a las testificaciones de las mujeres indias, por considerar que sus declaraciones no merecían fe. Pero por carta acordada de 9 de diciembre de 1583, la Suprema le ordenó al Tribunal que aceptara tales testificaciones y procediese en consecuencia contra quienes habían sido denunciados por indígenas. La Suprema estimó que, de mantenerse el predicamento del Tribunal, podían derivarse graves inconvenientes "al entender los tales confesores que cometen aquel delito que no se procede contra ellos". Para mitigar el problema de la fiabilidad de dichos testigos, la Suprema le advirtió que considerara su número y que tratara de "entender su trato y modo de vivir"53. Con todo, el Tribunal, si bien a futuro aceptará las denuncias de esos testigos, mantendrá una clara desconfianza hacia sus testificaciones, lo que se reflejará algunas veces en las penas impuestas a los delincuentes. Así, en las relaciones de causas correspondientes al año 1600, los inquisidores, para justificar unas sanciones diferentes a las establecidas en las instrucciones, manifiestan a la Suprema que "la calidad de las indias es que es gente muy fácil y mentirosa y que a cualquiera cosa que los quieran inducir lo hacen y dicen" ${ }^{15}$. El año anterior, el Tribunal había absuelto de la instancia al clérigo Pedro de Victoria, doctrinero en Nasca, entre otras razones por que las testigos eran indias y por lo tanto gente poco confiable ${ }^{55}$. Una situación similar se produce en 1603 en la causa de Miguel Jerónimo Caro ${ }^{56}$.

Si el propio Tribunal tenía desconfianza de las indígenas, con mayor razón los acusados tratarán de desconocer el valor probatorio de sus testificaciones. Concretamente, en la causa del jesuita Alejandro Venegas, de Santiago de Chile, el abogado de presos Alvaro de Ibarra sostiene que los testigos deben ser de buenas costumbres, no gente vil, ni de mal vivir, ni de corta capacidad,

52 Causas de Juan Angulo Cabrera, seguida en I580 (AHN, Enquisición, lib. 1028, f. 29!v.); de Manuel de Ortega, seguida en 1604 (AHN, Inquisicion, lib. 1029, f. 138); de Rafae! Venegas, seguida en 1658 (Manuscritos de José Toribio Medina (MM), t. 283, f. 312. Biblioteca Nacional de Chile); de Martín Morante, seguida en 1707 (José Toribio Medina, Historia ...de la lnquisición de Lima, op. cit, t. II, p. 203)

53 ANCh, Inquisición, vol, 486, f. 135.

s4 No obstante esas expresiones, los mismos inquisidores agregan que en los cnsos referidos piensan que las indias han dicho la verdad; pero por otra parte, la sanción que reciben los solicitantes, por lo menos en un aspecto, es más leve. AHN, Inquisición, lib. 1029, f.83.

3 AHN, lnquisicion, lib. 1028, f. 54lv.

56 lbid, lib. 1029, f. I38v y 333. En 1604, a Rodrigo Gómez de Ojeda se le dio menos pena por ser indígenas las testigos, AHN, Inquisición, lib. 1029, f. 138. 
fáciles o inconstantes; en suma no podían tener excepciones mayores y su número, para probar en plenitud el delito, debería ser 4 a lo menos. Pues bien, dicho abogado estima que, en esa causa, los testigos no eran suficientes ni por su número ni calidad. Con respecto a este último aspecto hizo presente que algunos eran indígenas, que se caracterizaban por su falta de capacidad y por la facilidad con que juraban y testificaban contra otros. Todo lo cual, dicho abogado lo fundamenta con la opinión de Solórzano Pereira, de quien cita su Politica Indiana ( Lib. $2^{\circ}$, cap. 28), en la parte que señala que 6 indígenas tienen la fuerza de un testigo español ${ }^{57}$.

A la hora de plantear excepciones, los reos y sus abogados a veces también descalificaban a testigos o comisarios argumentando que eran enemigos suyos. Así ocurre, por ejemplo, en la causa del clérigo Juan de Echavarría, procesado en 1572, quien señaló que el provisor y el notario del Cuzco eran sus enemigos capitales ${ }^{58}$; una situación similar se plantea en la causa del dominico Juan de Cobeñas, residente en Chile y procesado en 1579 , que pretendió tachar a ciertos frailes de su orden por considerarlos sus enemigos ${ }^{59}$. Los franciscanos Antonio de Oliva y Andrés Corral, residentes en la provincia de Tucumán y procesados en 1598 y 1600 respectivamente, alegan que el comisario era su enemigo ${ }^{60}$. Con todo, la defensa de los reos debía probar las tachas aducidas, por lo que el Tribunal no podía aceptar la simple declaración del acusado para rechazar una testificación. Aún más, en el siglo XVIII, debido a que en algunas causas el Tribunal aceptó las excepciones de los reos sin que hubiera probanza, la Suprema le ordenó que, siempre que éstos no esgrimieran pruebas al respecto, procediesen de oficio a su justificación ${ }^{61}$. En el siglo anterior, específicamente por carta de $1^{\circ}$ de octubre de 1662 , la Suprema le había ordenado al Tribunal, también a raíz del procedimiento seguido en una causa de solicitación, que no admitiere tachas de deshonestidad contra mujeres casadas. Y en caso de que tuviese dudas respecto a los testigos, le recomendaba que volviese a informarse verbalmente sobre el "crédito que debe dárseles"62.

Los reos, en su defensa, tenían derecho a presentar testigos que declararan a su favor. Con esos testimonios se pretendía contradecir las acusaciones del fiscal, justificar las tachas alegadas o resaltar la buena reputación de que gozaba el acusado. Por lo general, los reos citaban como testigos a gente princi-

57 Manuscritos de Medina . Biblioteca Nacional de Chile (MM), t. 283, f. 318.

58 AHN, Inquisicion, lib. 1027, f.33.

59 Ibid, fs. 236 y 274 .

66) AHN, Inquisición, lib. 1028, fs. 558 y y 601 ; lib. 1029, f. 79 .

or René Millar Carvacho, "Notas sobre el procedimiento inquisitorial desde la perspectiva del Tribunal de Lima". Revista Chilena de Historia del Derecho, Nª 9, Santingo, 1983,p. 337.

"2 ANCh, loquisición, vol. 491, f. 130. 
pal, que no mereciera reparos en cuanto a su fe y crédito. Pero, el Tribunal no podía considerar con valor probatorio absoluto las declaraciones de personas que tenían relación de amistad con el reo. Aún más, cuando los inquisidores, en 1655, en la causa de Rafael Venegas, acogieron las tachas alegadas por la defensa basándose en testigos que eran discípulos y amigos del sacerdote, fueron gravemente reprendidos, ordenándoseles que en lo sucesivo no cometieran esas irregularidades ${ }^{63}$.

En las causas de solicitación, la defensa concentraba buena parte de su esfuerzo en demostrar que los actos de que era acusado no correspondían a ese delito. La gran mayoría de los reos tendía a reconocer rápidamente los actos deshonestos que se le imputaban; sin embargo, rechazaban que ellos fueran constitutivos del delito en cuestión. En algunas oportunidades la defensa se limitaba a sostener que no había existido mala intención o que no se pretendió sentir mal del sacramento de la penitencia ${ }^{64}$. Pero, habitualmente, los reos alegaban que los hechos ilícitos se habían cometido fuera de confesión o que nunca se habian efectuado con pretexto de ella ${ }^{65}$. La precisión que hace la bula de Gregorio XV en cuanto a considerar como solicitación las proposiciones que se hicieran "inmediatamente con ocasión o pretexto de confesión", dejaba un pequeño resquicio que los sacerdotes acusados trataban de usar a su favor. Los tratadistas de moral, al analizar ese texto señalaban que la inmediatez a que se refería la bula suponía la inexistencia de interrupción entre la confesión y la solicitación ${ }^{66}$, por lo que algunos acusados, basándose en ese planteamiento, muchas veces se defenderán alegando que las acciones las cometieron luego de que había pasado un tiempo largo después de la confe$\operatorname{sión}^{67}$.

En ese sentido resulta muy interesante la causa seguida en 1653 a Rafae] Venegas, tanto por los argumentos que esgrime la defensa como por la cultura jurídica que refleja. En ella, el abogado de presos trata de demostrar que los hechos imputados a su defendido no correspondían a los sancionados por las bulas papales. Para que el reo quedara comprendido en la situación de ser

\footnotetext{
os lbid.

at Catsas de Clemente de Peñaiver (I582), AHN, Inquisición, lib. 1027, f, 273; de Esteban Zapata (i749), AHN, Inquisición, leg. 1656 , exp. 2.

6 Cousas de Juan de Cobeñas (1579); Rodrigo Barba (1583); Antonio Ordóñez de Villaquirán (1584); Pablo Rodríguez de Padilla (1599); Juan Prieto (1600); Bartolomé đe la Cruz (1600); García de Torres (1603). AHN, Inquisicion,lib. 1027, fs.89, 408, 564; lib. 1028, f. 559 y 587; lib. 1029, fs. 74,75 y 333 .

66 Juan Antonio Alejandre, op. cit., p. 16.

67 Causa de Joan Prieto, seguida en 1600; de Mateo Alvarado, procesado en 1599; de Fernando López, procesado en 1743; de Diego Chacón, procesado en 1760. AHN, Inquisición, lib. 1029, f. 74; lib. 1028 , f. 558 ; leg. 1656, exp. 1 y 2 ; leg. $2209, \mathrm{~N}^{\circ} 10$.
} 
solicitante antes de la confesión, como indican la bulas, el abogado estimaba que era "necesario que la solicitación o acto carnal sea inmediato al de la confesión, sin que medie otro acto diferente, ni pase tiempo alguno". Como, de acuerdo con su parecer, de las testificaciones se desprendía que eso no se daba, el reo no "incurría en dichas bulas". Toda esa argumentación, era fundamentada con la opinión de los "doctores" Sánchez, Freitas, Sousa, Castro Palao y Juan de la Trinidad, que se caracterizaban por ser especialistas en teología moral y, por lo menos uno de ellos, autor de un tratado específico sobre el delito de solicitación ${ }^{68}$. La acusación fiscal de haber solicitado simulando la confesión es contestada por la defensa diciendo que, según el tratadista Tomás Hurtado, para que aquello hubiese acontecido "es necesario que de orden suya la solicitada se de golpes en los pechos y se persigne haciendo y fingiendo que se esta confesando y juntamente el solicitante le haga la forma de la absolución aparente con ánimo de dar a entender y engañar a los circundantes que está confesando". Como esa situación no ocurrió, al decir del abogado Alvaro de Ibarra, tampoco en este caso debe aplicársele la bula de Gregorio V. Por último, la defensa también trataba de negar que hubiese existido solicitación al conocer carnalmente a una mujer en el confesonario, como el propio reo to había confesado. La argumentación no deja de ser curiosa, al respecto se señala, que aquello no obsta "porque lo primero no hubo gente delante que tal viese o entendiese, lo segundo no fue con hija de confesión, ni jamás trató de confesarla, ni fue simulando confesión, sino estando los dos en pie, ni fue dentro del confesonario sino a la puerta para cautelar y prevenir si viniese alguna gente". Y, en consecuencia, por esos motivos, que se fundan en la opinión coincidente de los tratadistas, entre los que cita a Tomás Hurtado y Juan de la Trinidad, "no se incurre en dichas bulas, ni contra sospecha en la $\mathrm{fe}^{169}$.

En suma, como los solicitantes estaban conscientes que a la Inquisición no le interesaba conocer los hechos que atentaran contra la abstinencia del clero, salvo que ocurrieran con motivo de la confesión, no tenían inconveniente en confesar tales situaciones, pero tratando de dejar en claro que habían acontecido fuera y sin relación con el sacramento. Con todo, el Tribunal rara vez acogerá ese tipo de argumentos y cuando lo llega a efectuar recibe la reprimenda del Consejo de la Suprema, como acontece justamente con la causa del jesuita Venegas, que comentamos ${ }^{70}$.

o* Tal es el caso, por ejemplo de Antonio de Suosa, autor de la obra Optisculum circa constitucionem sumimi pontificis Pauli $V$ in confessaris ad actus inhonestos foeminas in sacramentali confessione allicentes, Ullissipone, 1623.

${ }^{69} \mathrm{MM}, \mathrm{t} .283$, fs. 307,320 y 321 . 1662.

70 ANCh, Inquisición, vol. 491, f. 130. Carta de la Suprema al Tribunal de $1^{\circ}$ de octubre de 
En cuanto a las penas que imponía el Tribunal a estos delincuentes, por to general correspondían a las que estaban estipuladas en las instrucciones especiales que en 1577 le había hecho llegar la Suprema. Los jueces, siempre que consideraran que el delito había sido probado, condenaban al sacerdote a abjurar de levi y a oir la lectura de la sentencia en la sala de la audiencia del Tribunal, en presencia de los párrocos y de sus compañeros confesores y de los prelados de las órdenes, si era del clero regular. Las penas que casi nunca estaban ausentes eran la prohibición de confesar a perpetuidad hombres y mujeres, el destierro de los lugares en que había cometido los delitos, la reclusión por un tiempo determinado en algún convento y, de ser regulares, la ocupación del último lugar en el coro y refectorio y la privación de voz activa y pasiva. A ello se sumaban diversas penitencias, que iban desde los ayunos hasta las disciplinas, pasando por el rezo de los salmos penitenciales todos los viernes durante cierto tiempo.

No obstante lo anterior, muchas veces,el Tribunal en este aspecto se alejó de las normas generales, imponiendo penas distintas a las establecidas por la Suprema. Los inquisidores, amparándose en el arbitrio judicial que les reconocía la instrucción de 1577 sobre algunas penas, alteraban otras que eran inamovibles. Como lo hemos señalado en páginas anteriores, a los jueces se les reconocía autoridad para fijar a su arbitrio la duración del destierro, el lugar y tiempo de reclusión, la imposición de disciplinas y el tipo de penitencias; todo lo cual iba a depender "de la calidad de los delitos y gravedad y frecuencia de ellos e otras circunstancias que pueden mover a usar de rigor o moderación". Empero, en la misma instrucción se precisaba la forma como debía efectuarse la notificación de la sentencia y se advertía "que en cualquier evento los tales reos han de abjurar de levi y ser privados perpetuamente de la administración del sacramento"71.

El Tribunal, en algunas ocasiones no impuso la pena de privación perpetua de confesar por considerar que había circunstancias atenuantes, como la avanzada edad del reo, estado de salud o ignorancia del delito ${ }^{72}$. Esto último fue lo que argumentaron los inquisidores en la causa de Juan de Cobeñas, para suspenderlo por 8 años de confesar mujeres, no obstante haberse probado el delito por varios testigos y confesión parcial del reo. La Suprema, informada por la relación de la causa, modifica la sentencia y hace presente al Tribunal que, al fraile en cuestión, le "manden no confiese mujeres perpetuamente, no obstante lo que se proveyó en este negocio"73. A la Inquisición de Lima, sobre

7 ANCh, Inquisición, vol. 499, f. 23.

12 Causas de Francisco Gálvez ( 1594 ); Clemente de Peñalver (1582); y Juan de Cobeñas (I579). AHN, Inquisición, lib. 1028, f. 291; lib. 1027, fs. 89, 236 y 273.

73 AHN, Inquisición, lib. 1027, f. 236; 274. 
todo en sus primeros años de funcionamiento, se le hacía difícil imponer la pena de privación perpetua de confesar a los espontáneos o a los testificados por indígenas. Estimaba que esa sanción, en estas tierras, era de una gravedad extrema, porque los sacerdotes quedaban "imposibilitados de tener doctrina en toda su vida", es decir de acceder al principal medio de subsistencia para un clérigo $^{74}$. En otra causa, los inquisidores no se ajustan a esa pena, ni a la publicidad de la sanción, con el objeto de proteger la imagen de una orden religiosa. Esto aconteció en la causa seguida al jesuita Miguel Fuentes en 1581, respecto de la cual, aquéllos expresan, para justificar el proceder, que, por carta enviada por el Inquisidor General de 25 de agosto de 1580, se les mandaba que tuviesen "cuenta con honrar y favorecer las cosas de los de la Cornpañía y porque las testificaciones de haber solicitado in actu confesionis no son muchas mujeres"75.

Esa inquietud del Tribunal por proteger la imagen de determinadas órdenes religiosas con la disminución de las sanciones, también está presente en otras causas de este tipo. Así, a fines del siglo XVI, ante los numerosos procesos, que involucraban a miembros de las órdenes de San Francisco y de la Merced, el Tribunal optó por no ratificar las sentencias ante los curas y prelados de las órdenes, porque "como han salido tantos están muy lastimados y para el ejemplo de otros a habido bien de que poderle tomar...", a lo que se agrega "la calidad de las indias, que es gente muy fácil y mentirosa"76. Una situación parecida aconteció en la causa del franciscano Pedro Pacheco, condenado en 1598 por solicitar a varias monjas del convento de la Concepción de Lima. Los inquisidores en la relación de esa causa al Consejo le señalan que "la razón por lo que no se leyó la sentencia definitiva ante los prelados de las órdenes y sus compañeros confesores y curas de las parroquias fue por la honra del monasterio de las monjas de la Concepción que esta aquí con muy buena opinión" 77 .

También en relación con las penas, el Tribunal interpretó durante bastante tiempo que la prohibición de confesar perpetuamente establecida en las instrucciones de 1577 y reiterada por cartas acordadas, se refería sólo a las mujeres, quedando al arbitrio de los jueces el hacerla extensiva a los hombres. En la práctica, la prohibición perpetua se limitó de manera preferente a las mujeres, imponiéndose, con mayor frecuencia, respecto a la confesión de hombres

${ }^{74}$ Causas de Joan de Valdivieso (1597) y Antonio Hernández de Villarroel (1576). AHN, Inquisición, lib. 1028, fs. 532 y 584 ; lib. 1032, f. 19.

75 AHN, Inquisición, lib. 1027, 195. También, Medina, Inquisición de Lima, op. cit., t. I, p. 181.

${ }_{76}$ AHN, Inquisicion, lib. 1029, f. 83.

${ }^{n}$ Ibid., lib. 1028, f. 528v.

Missionalia Hispanica Hispania Sacra 48 (1996) 
una suspensión que variaba entre 2 o 4 años $^{78}$. A la vista de tal experiencia, la Suprema consideró que esa práctica del Tribunal producía numerosos inconvenientes "con descrédito de los mismos confesores", que quedaban en una situación desdorosa ante los penitentes al aparecer administrando el sacramento de manera limitada. En vista de ello, por carta acordada de 12 de enero de 1708 le ordenó que en todas las causas "que en adelante se ofrecieren de esta calidad y os pareciere corresponderles la privación de confesar sea perpetua y comprensiva igualmente de hombres y mujeres"79.

No obstante esas sentencias que, a veces tendían a mitigar la penalidad ${ }^{80}$, lo cierto es que las sanciones impuestas a estos delincuentes por el Tribunal tenían graves implicaciones para los afectados. Desde ya, como se ha explicado, quedaban privados de obtener beneficios eclesiásticos, por lo que la subsistencia material se les hacía muy difícil, sobre todo en el caso de los seculares. Los regulares tenían asegurado el sustento por su convento, pero como contrapartida debían aceptar una situación tremendamente humillante. Pero incluso a ellos a veces también se les presentaban difíciles situaciones económicas, como la que hace presente el dominico José Hurtado, que en 1795 suplica de la sentencia, solicitando que se le habilite "para predicar, confesar y obtener los oficios de su religión, debido a que se haya padeciendo bastantes necesidades por faltarle los auxilios que adquiría con los sermones con los que mantenía a su pobre madre viuda"81. La infamia en que caían era otro de los aspectos que resultaba muy duro para estos reos. Incluso, pareciera que algunas órdenes los expulsaban de ella. Así por lo demás, lo señala la defensa de Rafael Venegas, cuando expresa que cualquier pena que llegara a ser conocida por sus prelados, a parte de ser "gravísima por la infamia que contraería en su

${ }^{78}$ Con todo, a veces también se impuso in prohibición perpetua de confesar hombres, como acontece en las causas de Joan Silvestro (1597); de Alonso de Mendoza; de Francisco de Mesa; y Diego de Chaves, entre otros. lgualmente, en ciertas oportunidades, la suspensión se extendió incluso por 8 años, como ocurrío en la causa del agustino Cristobal de ...(1662). AHN. Inquisición, lib. 1028 , f. 532 y $580 \mathrm{v} ; 289 ; 559$ y 589 . Lib. 1031, f. 491 .

79 AHN, Inquisición, Jib. 498, f. 249. Hacia el año 1600, el Tribunal impuso a tres reos de solicitáción, en caso de quebrantamientos de las sanciones, la pena de galeras por tiempos variables, en vista de la gravedad de las faltas que habían cometido. En comunicación al Consejo, señalan que merecían esa pena pública, pero dado que las instrucciones no la establecían y que las sanciones no debran tener ese carácter, se limitaron a imponerla en caso de quebrantamiento. AHN, Inquisición, lib. 1028 , f. $606 \mathrm{v}$.

80 También se dieron casos en que la Suprema estimó que la pena impuesta eria excesiva, como aconteció en la causa de Cristobal de ...., de la orden de San Agustín, condenado en 1662, además de las sanciones ordinarias, a no decir misa durante 6 años. ANCh, Simancas, vol 4, f. 183.

${ }^{81}$ AHN, Inquisición, leg. 2216, № 6 y lib. 1026, año 1788. 
religión y luego al punto sus superiores le repelerían de ella", lo que podría significar "la ruina de su vida y riesgo de su salvación"82.

\section{LA ACTIVIDAD REPRESIVA}

La información estadística sobre este tema ha sido elaborada a partir de las relaciones de causas, a las que se agregan las alegaciones fiscales para el siglo XVIII ${ }^{83}$. Los cálculos efectuados no pasan de ser meras aproximaciones, pues si bien las relaciones cubren satisfactoriamente gran parte de la historia del Tribunal, puede que más de alguna se haya extraviado. Además, la revisión de las relaciones presenta variadas dificultades, originadas en una documentación en mal estado y en un delito que a veces va asociado a otros, lo que contribuye a que se cometan errores y omisiones en la recopilación de los datos. Para determinados análisis y comparaciones recurrimos a las cifras que entrega Jaime Contreras en su estudio sobre Las causas de fe en la lnquisición espa$\bar{n}$ ola, confeccionado también a partir de las relaciones de causas. Aunque los datos que entrega ese trabajo sobre la solicitación en Lima son inferiores a los nuestros, tienen la ventaja, por abarcar los diferentes delitos y tribunales, de permitir las comparaciones sobre una base estadística común.

\section{CUADro I}

LA SOLICITACIÓN EN EL TRIBUNAL DE LIMA. ACTIVIDAD REPRESIVA POR QUINQUENIOS 1570-1820

$\begin{array}{rrrrrr}1570-1575 & 5 & 1656-1660 & 1 & 1741-1745 & 3 \\ 1576-1580 & 19 & 1661-1665 & 1 & 1746-1750 & 4 \\ 1581-1585 & 11 & 1666-1670 & 1 & 1751-1755 & - \\ 1586-1590 & 2 & 1671-1675 & - & 1756-1760 & 3 \\ 1591-1595 & 5 & 1676-1680 & 1 & 1761-1765 & - \\ 1596-1600 & 29 & 1681-1685 & - & 1766-1770 & - \\ 1601-1605 & 7 & 1686-1690 & - & 1771-1775 & 1\end{array}$

n2 MM, t. 283, f. 324. Esas consecuencias, permiten comprender porqué algunos sacerdotes, no obstante haberse probado el delito, insistan en pedir una revisión de la sentencia, en un afán por mitigar las sanciones.

${ }^{\text {R3 }}$ Las alegaciones fiscales corresponden a resúmenes de procesos que efectuaba un relator del Consejo de la Suprema, para que este ratificara la sentencia dictada por el Tribunal de distrito. Forman parte de una modificación en el procedimiento inquisitorial acontecida en el siglo XVIll, que estableció la ratificación del Consejo para todas las sentencias dictadas por los tribunales.

Missionalia Hispanica

Hispania Sacra 48 (1996) 


\section{CUADRO I (CONT.) \\ LA SOLICITACIÓN EN EL TRIBUNAL DE LIMA. ACTIVIDAD REPRESIVA POR QUINQUENIOS 1570-1820}

$\begin{array}{llllll}1606-1610 & 2 & 1691-1695 & 2 & 1776-1780 & 3 \\ 1611-1615 & 1 & 1696-1700 & - & 1781-1785 & 1 \\ 1616-1620 & - & 1701-1705 & 1 & 1786-1790 & 4 \\ 1621-1625 & - & 1706-1710 & 2 & 1791-1795 & 4 \\ 1626-1630 & - & 1711-1715 & - & 1796-1800 & 4 \\ 1631-1635 & - & 1716-1720 & 1 & 1801-1805 & 1 \\ 1636-1640 & - & 1721-1725 & - & 1806-1810 & 1 \\ 1641-1645 & - & 1726-1730 & 2 & 1811-1815 & - \\ 1646-1650 & - & 1731-1735 & - & 1816-1820 & 3 \\ 1651-1655 & - & 1736-1740 & 4 & & \end{array}$

Fuente: Relaciones de causas y alegaciones fiscales. AHN, Inquisición, libs. 1025; 1026; $1027 ; 1028 ; 1029 ; 1031 ;$ y 1032 . También, legs. 1642; 1649;1654; 1656; 2209; y 3730.

En la represión de este delito por el Tribunal de Lima, a partir de un universo de 129 causas detectadas, pueden distinguirse tres fases: La primera, se extiende desde 1570 hasta 1615 y en ella se concentra la mayor parte de las causas de solicitación que se ventilan en este Tribunal a lo largo de toda su historia. Según nuestras investigaciones, para ese período hemos ubicado 81 causas, que representarían el 62,8 por ciento de todas las de ese delito que conoció el Tribunal (ver cuadro I). Con todo, la solicitación no está entre las causas que concentraron la mayor atención de los inquisidores de Lima. Las cifras de Jaime Contreras nos muestran que sólo significaron un 8,6 por ciento del total de las causas de fe vistas por el Tribunal en esos años.

\section{CuAdro II}

Causas de FE EN El TRIBUnal DE Lima. PERÍODO 1570-1614

$\begin{array}{lrr}\text { Proposiciones } & 285 & 37,1 \% \\ \text { Bigamia } & 100 & 13,0 \% \\ \text { judios } & 78 & 10,1 \% \\ \text { Santo Oficio } & 75 & 9,7 \% \\ \text { Solicitación } & 66 & 8,6 \% \\ \text { Superstición } & 50 & 6,4 \%\end{array}$




\section{CUADRO II (CONT.) \\ CAUSAS DE FE EN EL TRIBUNAL DE LIMA. PERÍODO 1570-1614}

\begin{tabular}{lrr} 
Luteranos & 47 & $6,1 \%$ \\
Musulmanes & 2 & $0,3 \%$ \\
Varios & 67 & $8,7 \%$ \\
& & \\
\cline { 2 - 2 } Total & $\mathbf{7 7 0}$ &
\end{tabular}

Fuente: Jaime Contreras, Las causas de fe en la Inquisición espaíola: 1570-1700. Análisis de una estadística. Versión mecanográfica. Copenhaguc, 1979, p. 28. Sc ha conservado la tipología delictiva que presenta el autor.

Tal como se aprecia en el cuadro II, entre los delitos que concentran la actividad represiva del Tribunal se destaca, en primer lugar, el de proposiciones. La Inquisición daba esta denominación a las palabras y expresiones atentatorias o contrarias a la fe y a la doctrina católica, incluidas las blasfemias y las palabras escandalosas. La preponderancia que tiene en esta primera etapa se explica porque el Santo Oficio, al establecerse en una región tendía a desterrar rápidamente todas aquellas manifestaciones u opiniones erróneos desde el punto de vista doctrinal, que se decían más que nada por ignorancia y que podían facilitar la penetración de herejías formales. La persecución de la bigamia, que aparece en segundo término, obedece a las mismas razones anteriores, con el agregado, de que estos territorios, por su lejanía, extensión y peculiaridades migratorias, se prestaban para la perpetración de dicho delito. Otro delito que concita el interés inquisitorial es el judaísmo, cuya represión está vinculada a la presencia de grupos de inmigrantes de ascendencia portuguesa. También resulta importante en esta etapa, la represión a aquellos que dificultaban la jurisdicción del Santo Oficio, lo cual era consecuencia de la necesidad inicial que tenía de hacerse respetar e incluso temer.

La segunda fase se extiende de 1616 a 1735 y se caracteriza por una paralización casi total de la actividad represiva hacia los solicitantes. Para esos extensos 119 años sólo hemos detectado 12 causas de ese tipo y, aún más, según nuestras pesquisas, entre 1616 y 1655 el Tribunal no habría procesado a ningún solicitante (ver cuadro I). Con todo, eso no implica que la Inquisición de Lima hubiese estado inactiva, muy por el contrario, en aquellos años se produce un intenso movimiento represivo, que se centra prácticamente en un único delito. El Tribunal orienta la casi totalidad de sus recursos humanos y materiales a la persecución de los falsos conversos de origen portugués. Aparte

Missionalia Hispanica Hispania Sacra 48 (1996) 
de los factores religiosos que motivan esa acción, hay otros de carácter económico, que explican la unilateralidad con que actuó el Tribunal. Dado que la mayoría de los judaizantes se dedicaban al comercio, algunos con gran éxito, las confiscaciones de sus bienes, por la magnitud de recursos involucrados, se transformaron para el Tribunal en un objetivo prioritario, en la medida que podían implicar, y de hecho así ocurrió, una gran solución a sus problemas financieros ${ }^{84}$. En esta segunda fase, los otros delitos en los que se concentra la actividad, según las estadísticas de Jaime Contreras, son la bigamia, que representa más del 17 por ciento de todas las causas, y las proposiciones, que significan el 12,6 por ciento de ellas, en un notorio descenso con respecto a la fase anterior (ver cuadro III). En cambio, las causas de solicitación escasamente corresponden al 2,2 por ciento del total ${ }^{85}$.

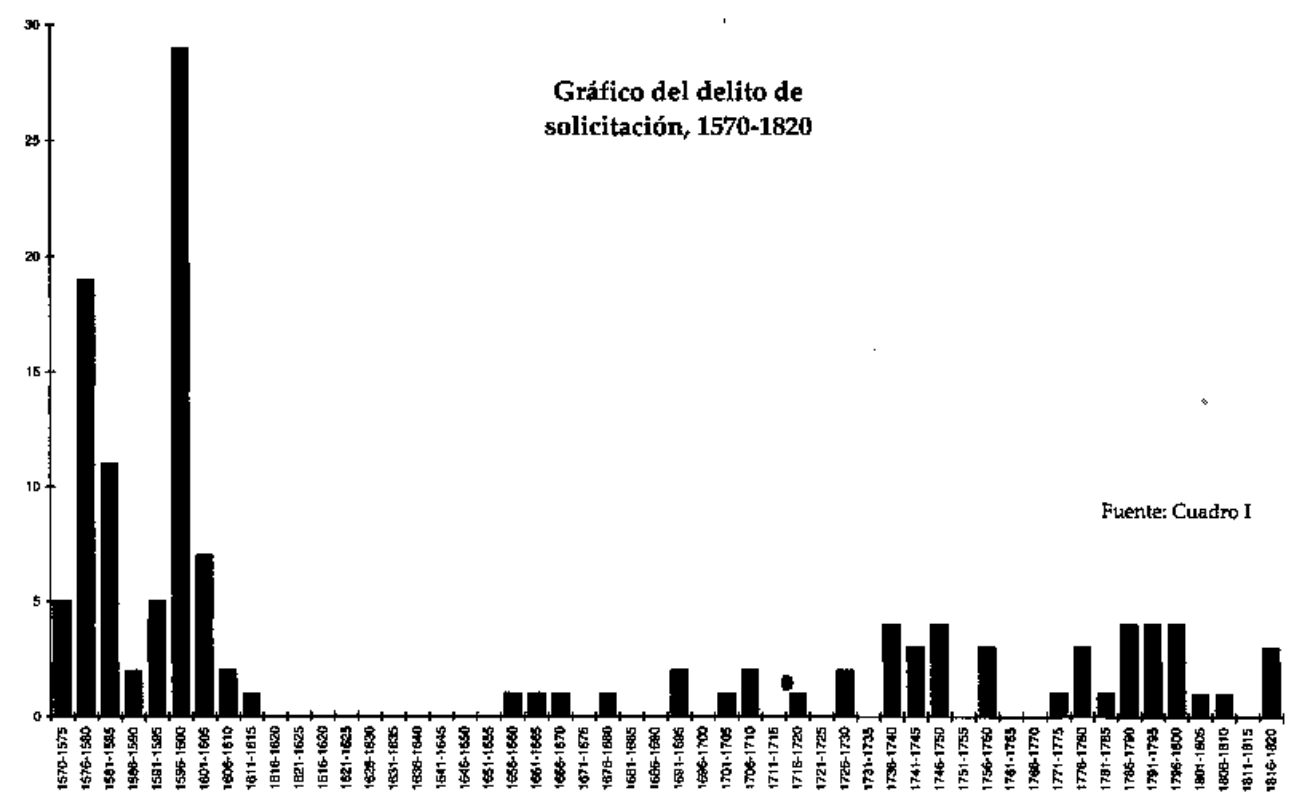

*a Sobre ese tema René Miftar Carvacho, "Las confiscaciones de la Inquisición de Lima a los comerciantes de origen judio-portugués de la gran complicidad de 1639". Revista de Indias, $\mathrm{N}^{\circ} 171$, Madrid, 1983.

\&. Las estadísticas de Jaime Contreras llegan sólo hasta el año 1700. 


\section{CUADRO III}

CAUSAS dE FE EN EL TRIBUNAL DE LIMA. PERÍODO 1615-1700

$\begin{array}{lrr}\text { Proposiciones } & 51 & 12,6 \% \\ \text { Bigamia } & 71 & 17,5 \% \\ \text { judios } & 145 & 35,7 \% \\ \text { Santo Oficio } & 16 & 3,9 \% \\ \text { Solicitación } & 9 & 2,2 \% \\ \text { Superstición } & 69 & 17,0 \% \\ \text { Luteranos } & 10 & 2,5 \% \\ \text { Musulmanes } & 0 & 0,0 \% \\ \text { Varios } & 35 & 8,6 \% \\ & - \\ \text { Total } & \mathbf{4 0 6} & \end{array}$

Fuente: Jaime Contreras, op. cit. Las estadísticas de este autor llegan sólo hasta el año 1700.

La tercera y última fase se extiende de 1736 a 1820 y se caracteriza por un aumento significativo en el número de procesados por este delito con respecto a la etapa anterior. Nuestras recopilaciones nos han permitido ubicar 36 causas de solicitación (ver cuadro I), que consideradas de manera aislada pueden parecer una cantidad exigua, pero vistas comparativamente con los demás delitos, esa percepción cambia de forma sustancial. De hecho, la solicitación se transforma, a partir de mediados del siglo XVIII, en el delito que concentra la mayor parte de la actividad represiva del Tribunal. En efecto, si tomamos los datos disponibles para el período 1750-1818, la solicitación representa el 27 por ciento de las causas, seguida por la bigamia, con el 25,7 , las proposiciones con el 13,5 y la hechicería con el 9,5 por ciento (ver cuadro IV). Estas cifras nos muestran una reorientación de la actividad del Tribunal, el cual, ante la desaparición de los herejes por antonomasia, se vuelca hacia quienes realizan acciones o emiten opiniones sospechosas de herejía. Entre estos úitimos, la solicitación aparece como el delito más perseguido debido, por lo menos en parte, a las orientaciones de la Suprema, que cada cierto tiempo hace llegar algunas instrucciones al respecto, como las referentes a los confesonarios y la que daba a conocer la bula de Benedicto XIV de $1741^{86}$. La repre-

ax En las causas del franciscano Diego de Chacón y del clérigo Vicente Gómez de Castilla, vistas en 1759, tanto la defensa de los reos como la Suprema hacen referencias expresas a esa bula. AHN, Inquisición, leg. 1656, exp. l; leg, 2209, $\mathrm{N}^{\circ} \mathrm{l} 0$.

Missionalia Hispanica

Hispania Sacra 48 (1996) 
sión del Tribunal de Lima a los solicitantes también hay que verla dentro de una política que tiende a mejorar el comportamiento del clero. De hecho, además de ese delito, en esa época se perseguía a los falsos celebrantes y a quienes se casaban siendo sacerdotes. Con todo, no hay que perder de vista que la actividad global del Tribunal en esta tercera fase es muy limitada con respecto a las dos anteriores. El número total de procesados es sustancialmente más bajo y es en ese contexto, en que la solicitación, junto a la bigamia, las proposiciones y la hechicería, ocupan el centro de las preocupaciones del Tribunal.

\section{CUADRO IV \\ CAUSAS DE FE EN EL TRIBUNAL DE LIMA. PERÍODO 1700-1818}

\begin{tabular}{lrrrrr} 
& \multicolumn{2}{c}{$1700-1749$} & \multicolumn{2}{c}{$1750-1818$} \\
Proposiciones & 32 & $10,1 \%$ & 10 & $13,5 \%$ \\
Bigamia & 83 & $26,3 \%$ & 19 & $25,7 \%$ \\
judíos & 7 & $2,2 \%$ & 00 & $0,0 \%$ \\
Santo Oficio & 3 & $0,9 \%$ & 1 & $1,4 \%$ \\
Solicitación & 17 & $5,4 \%$ & 20 & $27,0 \%$ \\
Superstición & 83 & $26,3 \%$ & 7 & $9,5 \%$ \\
Luteranos & 24 & $7,6 \%$ & 1 & $0,0 \%$ \\
Musulmanes & 00 & $0,0 \%$ & 0 & $0,0 \%$ \\
Falsa celebración & 16 & $5,1 \%$ & 9 & $12,1 \%$ \\
Libros prohibidos & 00 & $0,0 \%$ & 4 & $5,4 \%$ \\
Varios & 12 & $3,8 \%$ & & 3 & $4,1 \%$ \\
Total & & & & &
\end{tabular}

Fuente: René Millar, La Inquisición de Lima en los siglos XVII y XIX. Tesis doctoral, inédita, Universidad de Sevilla, 1981.

Para efectuar un análisis comparativo con los demás tribunales inquisitoriales, nos topamos con un serio inconveniente derivado de la falta de información para el siglo XVIII y comienzos del XIX. El trabajo de Jaime Contreras sólo cubre hasta el año 1700 , debido a que las relaciones de causas dejan de enviarse a partir de esa fecha. En resumidas cuentas sólo disponemos de referencias completas para el caso de dos tribunales peninsulares, los de Toledo y Cuenca. Para el resto, como está dicho, disponemos de información hasta 
1700. Sin embargo, a pesar de esas limitaciones, es posible apreciar algunas correlaciones entre lo que acontece en la península y la situación que se da en el Tribunal de Lima. En primer lugar, en aquellos también se aprecia una etapa inicial, considerada desde el momento que el santo Ofício asumió la juris-dicción sobre el delito, hasta 1620 aproximadamente ${ }^{87}$. En ella figura, en términos absolutos, un número importante de procesos de este tipo, que en el caso del Tribunal de Toledo llegan a los 67 y en el Cuenca a $34^{88}$. Con todo, su significación con respecto al resto de los delitos es todavía menor que en la Inquisición del Perú, pues esas cifras representan porcentajes inferiores al 3 por ciento del total de las causas tramitadas por ellos. Sin lugar a dudas, en ese período y para dichos tribunales, la solicitación era un delito marginal, que revestía menos interés que para el de Lima.

Otra etapa puede distinguirse en los tribunales peninsulares indicados, la que se extendería en términos generales desde la década de 1620 hasta la de 1730. Lo más característico de ella es que, después unas tres décadas de cierto retroceso, en ambos se mantiene una actividad más o menos constante y en niveles levemente inferiores a la etapa anterior, con la diferencia que en la segunda, las causas de solicitación han incrementado su incidencia con relación al total de los procesos tramitados por los tribunales. Todo parece indicar que en la península, las oleadas persecutorias de los herejes formales (judaizantes y mahometanos) no alcanzaron a concentrar la actividad de una manera tan unilateral como en Lima, salvo en un lapso más bien breve. El repunte de las causas de solicitantes que se produce a continuación, estaría

\footnotetext{
87 La periodificación que planteamos para los tribunales peninsulares no corresponde exactamente a ln que proponen los autores estudian aquellos tribunales, pero la elaboramos a partir de la información estadística que ellos aportan.

8R JEAN PIERRE DEDIEU, "Les causes de fot de l'Inquisition de Tolede (1483-1820)". Melanges de la Casa de Velazquez. Tome XIV (1978), appcndice It. Adelina Sarrión, op. cit., p. 78. Esta autora, merced a la riqueza documental que se conserva del Tribunal de Cuenca, pudo realizar un análisis muy profundo con respecto a la significación que para él quvo el delito en cuestión, al tener acceso no sólo a los procesos incoados, sino también a las denuncias efectuadas, muchas de las cuales no daban origen a la formación de causa. Al respecto, nosotros, para el caso de Lima disponemos de una información parcial que entrega la visita del tribunal efectuada por Rtiz de Prado en 1587. Allí, en unos expedientes sobre denuncias de solicitación figuran 80 casos para el petíodo 1570-1588 y nosotros hemos detectado para esa misma etapa un total de 37 procesos efectivos, lo cual nos indicarín que el tribunal procesó alrededor del 46 por ciento de los denunciados (ANCh, Simancas, vol. 29, f. 74 y ss.). Pero lo anterior no debe de extraĩar porque en todos los delitos quedaba un atto porcentaje de denuncias sin transformarse en causa. Así tenemos, que los procesos por bigámia en el período mencionado alcanzarían según Ruiz de Prado a 21 y las denuncias a 143. Paulino Castañeda Delgado y Pilar Hernández Aparicio, " La vișita de Ruiz de Prado al Tribunal del Santo Oftcio de Lima". Anuario de Estudios Hispano-americanos. Sevilla, 1984, pp. 3 y I I. Adelina Sarrión estima, para el tribunal de Cuenca, en torno al 80 por ciento el número de denuncias que en el delito de solicitación quedaba sin concluir, saperando en ese aspecto a los demís delitos, opl. cil., D. 82 .
}

Missionalia Hispanica

Hispania Sacia 48 (1996) 
vinculado a las orientaciones de la Suprema, que instan a los tribunales a poner en aplicación la bula de Gregorio XV, después de las dudas que se suscitaron por la jurisdicción copulativa con los obispos. En consecuencia, en esta etapa no existe una clara correspondencia con lo que sucede en Lima, pues, como hemos visto, aquí la solicitación no fue considerada, al punto de que casi no hubo procesos. El factor clave de esto fue el de los falsos conversos, que condicionaron la actividad del Tribunal indiano, no obstante los requerimientos que sobre la persecución a los solicitantes hizo la Suprema a raíz de la publicación de la bula papal. Los inquisidores de Lima se limitaron a publicar en 1630 el edicto especial comentado en páginas anteriores, al parecer sin interesarse por esos procesos, ni, por lo mismo, insistir ante los comisarios y demás funcionarios sobre la materia.

La tercera etapa en los tribunales de Cuenca y Toledo se extendería desde la década de 1730 hasta 1820 y en ella los delitos de solicitación, en términos absolutos, tenderían a disminuir con respecto a la anterior. Sin embargo, su importancia con respecto a los otros delitos aumenta de manera sustancial, al punto que en el Tribunal de Toledo, las causas de solicitación representan el 23,7 por ciento del total, lo que hace de ellas las segundas en importancia después de las palabras escandalosas ${ }^{89}$. Por algunos antecedentes parciales que aporta Adelina Sarrión para otros Tribunales, pareciera que en la península es más o menos general la tendencia a una mayor importancia relativa de la solicitación durante el siglo XVIII. En suma, en ese aspecto tendríamos nuevamente una correspondencia con lo que acontece en el Tribunal de Lima, en el que la solicitación se transformó, en esa fase, en el delito que concentró la mayor actividad. Este hecho, unido a los otros procesos que de preferencia involucran a eclesiásticos, nos lleva a reiterar lo que ya habíamos señalado en un trabajo de 1981, en cuanto a que la Inquisición de Lima, a medida que avanza en el siglo XVIII se fue transformando en un tribunal que tenía al clero entre sus pacientes más importantes. A conclusiones similares llega Jean Pierre Dedieu para el caso del Tribunal de Toledo cuando señala que, durante el siglo XVIII, éste redujo más y más su función a un corte disciplinaria del cle$\mathrm{ro}^{90}$. Sin embargo, lo anterior no nos puede hacer perder de vista el significado real que tuvo la solicitación para el Santo Oficio. En los tribunales peninsulares, dicho delito representó entre el 2 y el 5 por ciento del total de causas que siguieron ${ }^{91}$. En el caso del Tribunal de Lima el delito tuvo más importan-

\footnotetext{
${ }^{89}$ Las palabras escandalosos constituyen el 36,1 por ciento de las causas vistas por el Tribunal entre 1740 y 1820 . Jean Pierre Dedieu, op. cit., appendice IL.

90 JEAN-PIERRE DEDIEU, L'administration de la foi. L'Inquisition de Tolède (XVI-XVIII siècle). Casa de Velázquez. Madrid, 1989, p. 351.

"11 Adelina SARrion, op. cil., p. 106.
} 
cia, pues implicó alrededor del 7 por ciento de su actividad, quedando tras las proposiciones, la bigamia, la hechicería y el judaísmo. A pesar de esa diferencia con la península, para los inquisidores limeños este delito tuvo una significación más bien secundaria, pues cada uno de aquellos otros delitos representaba sobre el 13 por ciento de la actividad.

\section{EL TRANSGRESOR Y LA VICTIMA}

\section{a) Tipología del delincuente}

Entre los procesados por el delito de solicitación predominaban los miembros del clero regular, que representaban el 60 por ciento del total de inculpados. Es posible que ese predominio corresponda a una división equivalente con respecto al tipo de clero existente en el virreinato. Sin embargo, dado lo fragmentario de los antecedentes disponibles nada se puede asegurar en ese aspecto. Por lo demás, nosotros tendemos a pensar que también pudo influir en aquella situación, la preponderancia que tuvieron los religiosos en el servicio de las doctrinas, sobre todo a fines del siglo XVI y comienzos del XVII, como lo deja de manifiesto el Arzobispo de Lima Toribio de Mogrovejo en $1602^{92}$. Hay que considerar que una proporción muy importante de los procesados se desempeñaba como doctrinero. Ahora bien, durante el siglo XVIII, tienden a equipararse los regulares con los seculares, coincidiendo con una menor presencia de los primeros en las doctrinas. Por otra parte, el predominio de los regulares en el distrito del Tribunal limeño coincide con la situación que se produce en la península, en el caso específico de la Inquisición de Cuenca, en la que se da la misma proporción que en América. Adelina Sarrión atribuye el fenómeno peninsular a la numerosa presencia de los regulares en el mundo rural, especialmente en la Cuaresma y Semana Santa ${ }^{93}$.

$\mathrm{Si}$ analizamos a los solicitantes de acuerdo a la orden religiosa a la que pertenecían, nos encontramos con que los franciscanos constituían la amplia mayoría de los reos, al representar el 39,7 por ciento de ellos; a continuación, también a gran distancia de los religiosos de las demás órdenes, le seguían los mercedarios con el 25,6 por ciento; luego se ubicaban los dominicos, con el 12,8 por ciento, para terminar con los agustinos y jesuitas, que con el 10,25 por ciento para cada uno, eran los menos numerosos. Es muy probable que la abultada cifra de reos pertenecientes a la orden de San Francisco correspondiera al predominio cuantitativo que ella tería en el virreinato, como se des-

92 Rubén Vargas Ugarte, Historia de la lglesia en el Perti. Burgos 1959, t. ll, pp. 190 y 191.

93 ADELINA SARRIÓN, op. cit., p. 239. 
prende de la información que entrega Antonio Vázquez de Espinosa para fines de la década de $1610^{94}$. Con todo, no parece que esa fuese la única razón para explicar esa amplia preponderancia franciscana entre los solicitantes. De partida, está el caso de los dominicos, que según Vázquez de Espinosa eran la segunda orden en cuanto a la cantidad de miembros, no obstante lo cual ellos aparecen muy poco involucrados en este delito. A eso hay que agregar otro hecho, los dominicos ocupaban la mayoría de las doctrinas de indios, sin que tampoco esto quedara reflejado en un número proporcional de solicitaciones. En consecuencia, es preciso pensar en factores relacionados con la formación y selección de los miembros para explicar el comportamiento de los franciscanos, a los que podría añadirse la tendencia que manifestaban a un mayor contacto con la población a raíz de su carácter mendicante. Cabe hacer notar que en la Inquisición de Cuenca los franciscanos también constituyen la mayoría de los solicitantes y Adelina Sarrión atribuye ese hecho a la fuerte presencia de la orden en Castilla ${ }^{95}$. Lo que si no guarda relación con la península es la importante participación que en el tribunal limeño les cabe, en este delito, a los mercedarios. En Cuenca no figuran para nada, en cambio en Lima conforman, a gran distancia del resto, el segundo grupo entre los solicitantes, al punto que en conjunto con los franciscanos representan los dos tercios de tales delincuentes. Por otra parte, esa orden no se encuentra entre las más numerosas del virreinato, aunque sí tenía una importante presencia en las doctrinas de indios.

La edad de los solicitantes fluctuaba mayoritariamente entre los 40 y los 56 años, ya que nada menos que el 49,4 por ciento de ellos queda comprendido en torno a esos límites. Con todo, un porcentaje no despreciable, igual al 17 por ciento del total, tenía más de 60 años, e incluso se da el caso de algunos reos mayores de 70 años ${ }^{96}$. Pero, lo más significativo tiene que ver con el

94 ANTONIO VÁZQUEZ DE ESPINOSA (Compendio y descripción de las Indias Occidentales. Historia 16, Madrid, 1992, t. II, p. 623), señala que el número de regulares por orden religiosa, en el virreinato peruano era el siguiente: San Francisco, 789; Santo Domingo, 694; San Agustín, 546; La Merced, 541; y la Compañía de Jesús, 412. Las doctrinas que poseian las brdenes según dicho autor eran: Santo Domingo, 105; La Merced, 72; San Francisco, 7I; san Agustín, 31; y La Compañín, 16.

ys Adelina Sarrión, op. cit., p. 249.

${ }^{6}$ AHN, Inquisición, lib. 1032, f. \$18v. Al respecto podria citarse la causa del jesuita Francisco Ramírez de los Olivos, natural de Lima, de 70 años, procesado en 1667 , que se refocilaba haciendo interrogatorios escabrosos a sus penitentes. Según el físcal, les preguntabn "lo que sentían cuando el hombre les metía el miembro y si se lo metían por atrás y si les gustaba más si cra más grande". También se le acusa de obligar a algunas mujeres en la confesión a que le dijeran "taita mío, mi vida, mis ojos, mi corazón, mi alma". $Y$ de preguntar a otra mujer casada "que cómo eran los actos carnales que tenf́a con su marido y le decía que no había de ser más que un acto por cumplir con la obligación y sin usos de posturas extraordinarias sin embargo de ser su marido y que de lo contrario se enojaría este reo" 
elevado número de solicitantes menores de 40 años, los que constituían un 31,2 por ciento del total. Esto último llama la atención, porque según lo dispuesto en el Segundo Concilio Limense, en concordancia con lo instituido en otros concilios provinciales, como el de Toledo de 1582, los confesores de mujeres debían tener 40 años. Por otra parte, también hay que considerar que para ser párroco, ya sea de indios o españoles, sólo se exigían 25 años como edad mínima, con lo cual, aquella anterior disposición, quedaba limitada a los sacerdotes que no gozaban de ese beneficio.

De la fragmentaria información disponible pareciera que la gran mayoría de los solicitantes eran doctrineros o colaboradores de una doctrina, especialmente en tiempos de Cuaresma y Semana Santa. Los que figuran como párrocos de españoles son muy pocos; pero, habría que señalar que las relaciones de causas eran poco explícitas a la hora de indicar el cargo o beneficio eclesiástico que desempeñaba el reo, por lo que resulta imposible aventurar alguna conclusión al respecto. Lo que sí parece claro es que los miembros involucrados del alto clero serían poquísimos. Sólo hemos detectado a 3 prebendados y 1 prior y pensamos que, dada la relevancia de los cargos, esa información no se le omitía al Consejo y, por lo tanto, la fuente, en este aspecto, refleja la realidad. Por lo demás, los inquisidores, en esos casos, antes de proceder pedían instrucciones a la Suprema ${ }^{97}$.

El nivel educacional de los solicitantes, de acuerdo con todos los indicios, sería muy bajo. En este aspecto la fuente también es poco explícita, al extremo que, en la mayoría de las relaciones, ese tipo de información no figura. Pero, por otra parte, en algunas causas sí se señala y da la impresión que se hace por el carácter excepcional que tenía. Así, los inquisidores destacan de manera especial cuando alguno de los reos sabe algo de gramática o ha estudiado principios de gramática. En un caso se menciona que ha estudiado latín, pero con más frecuencia se indica que el reo "sabía algo de gramática, mal sabi$\mathrm{da}^{198}$. Y en una sola causa se señala que el reo era un licenciado, hecho que se recalca, pues junto con indicarse el grado se señala que había estudiado gramática, parte de fílosofía y algo de moral ${ }^{99}$. Da la impresión que los propios inquisidores tenían claro que la mayoría de los solicitantes eran gente de poca literatura, como pareciera desprenderse de una comunicación a la suprema

\footnotetext{
97 ANCh, Inquisición, vol. 496, f. 129.

98 Causas de Hernando de Espinar, Joan de Valdivieso, Gaspar Frías, Mateo Alvarado, Joen Prieto, Diego Dávila, Gutiérrez de Cárdenas. AHN, Inquisición, lib, 1027, f. 285 y 389; lib. 1028, fs.531, 532 y 558 ; lib. 1029 , fs. 74,134 y 476 .

99 Causa de Clemente Paz y Miranda, procesado en 1741. AHN, Inquisición, leg. 1656, exp. 2. Fuera de los canónigos, otro eclesiástico que tenía estudios superiores a la media es Rafael Venegas, de la Compañía de Jesús, quien después de seguir gramática, estudió artes y teología. MM, t. $283, f$. $140 \mathrm{y} s \$$.
} 
referente a un grupo de esos reos de la provincia de Tucumán, en que le indican que eran todos "gente muy idiota y perdida" 100 .

Por último, en lo que toca a las zonas en las que se cometía el delito, de la información disponible se desprende que existía un leve predominio de las áreas rurales sobre las urbanas. Entre un 52 y 53 por ciento de las solicitaciones se producían en lugares como Chilca, Tumbes, Tarija, Santa Rosa de Ocopa, Chunchanga, Atún Huaylas, Camaña, Loxa, Nasca y Chachapoyas. Aunque la precisión de esos porcentajes es discutible y perfectamente el resultado podría ser inverso y por lo tanto a favor de los centros urbanos, lo que no ofrece dudas es la fuerte presencia del mundo rural. Y esto es un hecho excepcional en lo que respecta al Tribunal de Lima, pues su implantación en ese ámbito fue siempre muy marginal. Desde su etapa fundacional hasta su extinción privilegió a la ciudad, en torno a ella se estructuró toda su red administrativa. Los comisarios, es decir los representantes del Tribunal en el territorio distrital, los encargados de recibir las denuncias, se concentraban en las principales ciudades. Si a eso se agrega el hecho de que aquí no funcionó la institución de la visita del distrito ${ }^{101}$, tenemos que el mundo rural estuvo muy mal cubierto por las redes inquisitoriales. Esto queda de manifiesto en la actividad procesal de esta Inquisición, en la que predominan los inculpados de las ciudades más importantes ${ }^{102}$. En consecuencia, el fenómeno que acontece con la solicitación resulta bastante especial. Y ello fue posible, porque en dichas áreas se daban una serie de condiciones que facilitaban la perpetración del delito. Podría argumentarse con razón, que una situación parecida también era posible que se diera con otros delitos; sin embargo la diferencia estuvo en que la solicitación rural llegaba con más frecuencia a conocimiento del Tribunal por la denuncia que muchas veces efectuaban las víctimas, obligadas por otros confesores; sin esa presión es difícil que ese delito cometido en zonas aisladas hubiese sido conocido por los inquisidores.

100 AHN, Inquisición, lib. 1029, f. 83. También, J.T. MEDiNA, La Inquisición en las provincias del Plata, op. cit., p. 126.

bol La visita del distrito fue una institución que tuvo gran importancia en los tribunales peninsulares y fue uno de los medios que permitio un efectivo control de la población rural. Ver Dominique Peyre, "La Inquisición o la política de la presencia", en Bartolomé Bennassar, La Inquisición española; poder político y control social. Editorial Crítica. Barcelona, 1981. En Lima, los inquisidores fundadores Serván de Cerezuela y Antonio Gutiérrez de Ulloa, por carta de enero de 1570 hicieron presente al Consejo acerca de la imposibilidad de llevar a cabo la visita, por la excesiva distancia y falta de personal. En 1574 el Consejo autorizó a que ellas no se realizaran y ordenó que fuesen reemplazadas con el envío a los comisarios cada tres años de los edictos de fe para su publicación. ANCh, Inquisicion, vol. 483 , fs. 323 a 331.

102 RENÉ MILLAR, La Inquisición de Lima en los siglos XVIII y XIX, op. cit. 
La mayoría de las solicitaciones que se producían en el mundo urbano tenían lugar en Lima, nada menos que el 22 por ciento del total de causas tramitadas por el Tribunal se originaba en dicha ciudad. A continuación, figuran Santiago de Chile y el Cuzco con alrededor del 7 por ciento, aunque en el caso de la segunda de ellas, las relaciones no distinguen entre los casos que se producen en la ciudad o en las zonas rurales circundantes (sus términos). $\mathrm{Si}$ vemos la distribución de los solicitantes por provincias, nos encontramos con que la gran mayoría correspondía al Perú, seguido de Chile, Quito y Charcas. Con todo, en este aspecto, lo que más llama la atención es la gran cantidad de causas originadas en la provincia de Tucumán, pues ellas constituyen más del 21 por ciento del total de solicitantes procesados por el Tribunal. No tenemos una explicación clara sobre esa situación. ¿QQué es lo que diferencia a esa provincia de otras? $i$ Su aislamiento? $i$ Su marginalidad? Pero, no cabe duda que en el extenso distrito de la Inquisición de Lima había numerosas zonas que tenían esas características y en ellas no aparece esa explosión de solicitantes y solicitaciones. Sin desechar la significación que pudo tener el factor aislamiento y las dificultades que encontraba la Iglesia para desarrollar su acción evangelizadora, pensamos que pudo haber desempeñado un papel importante la presencia inquisitorial en esos territorios. En otras palabras, es muy posible que en la represión del delito en dicha provincia, la figura del comisario haya sido determinante.

Existen varios indicios que tienden a confirmar esa explicación. En primer lugar, la casi totalidad de las causas corresponden a solicitaciones que se producen en áreas rurales, normalmente en Cuaresma y Semana Santa, afectan por lo general a mujeres indias, los involucrados pertenecen de preferencia a las órdenes de San Francisco y la Merced y la mayoría de los procesos se concentran a fines del siglo XVI y comienzos del XVII. En segundo lugar, el comisario de la Inquisición en Tucumán por esos años era el padre jesuita Francisco de Angulo. En las relaciones aparecen diversas referencias a dicho comisario efectuadas por los acusados, las que por lo general apuntan a descalificarlo. También figuran declaraciones que aluden a los padres de la Compañía, como las que efectúan algunas solicitadas por el mercedario Diego de Sanabria, quien les habría indicado que no concurrieran ante el comisario si este las llamaba y que tampoco se confesaran con los dichos sacerdotes ${ }^{103}$. En consecuencia, pareciera que los jesuitas, tanto a través del comisario Angulo, como de los miembros de la orden en general, tuvieron una especial preocupación por reprimir el delito de solicitación en esa provincia. Es muy posible que esa actitud hubiese obedecido a razones meramente jurídicas y espiritua-

${ }^{103}$ AHN, Inquisición, lib. 1029, f. 89.

Missionalia Hispanica

Hispania Sacra 48 (1996) 
Ies, aunque no puede descartarse del todo la posibilidad de que también estuviese influida por desavenencias entre las órdenes religiosas.

En suma, el solicitante tipo era un sacerdote preferentemente del clero regular, franciscano o mercedario, de alrededor de 40 años, bastante inculto, que por lo general se desempeñaba como cura doctrinero en los pueblos de indios, aunque no faltaban los residentes urbanos, que acosaban a sus víctimas en Iglesias y conventos de ciudades importantes, comenzando por Lima.

\section{b) Caracterización de la víctima.}

Lamentablemente, la información que sobre este tema nos entregan las relaciones de causas son escasas y fragmentarias, por lo que nuestro análisis en esta parte tendrá un carăcter aún más provisional que en la anterior. Del total de procesos fichados, disponemos de referencias sobre las víctimas en el 60 por ciento de los casos, lo cual si bien es poco satisfactorio, creemos suficiente para que las pocas conclusiones no resulten distorsionadoras de la realidad. Por otra parte, al hablar de las víctimas debe tenerse presente que, a diferencia de los acusados, en cada proceso son varias las involucradas. Las causas en que figuran dos o tres testigos directos son una ínfima minoría y por el contrario la tendencia es que el número de mujeres solicitadas por cada reo fuese superior a cinco, llegando incluso al extremo ya comentado de 90 testificaciones en un proceso. Pero, este mismo fenómeno dificulta la rigurosidad del análisis, porque las relaciones en los casos de denuncias numerosas no entran a describir las características de cada una de las testigos, conformándose con las menciones de algunas o con referencias genéricas.

A partir de esos antecedentes habría que señalar que, desde el punto de vista racial, entre las víctimas predominaban las mujeres indígenas. Ellas están presentes en el 61 por ciento de las causas que nos entregan información al respecto. Y para formarse una idea acerca del número de ellas que estaba involucrado en estos procesos, en términos absolutos, debe considerarse que, regularmente, en tales casos los testigos superaban la decena y por ende las indígenas que aparecen declarando contra los reos llega fácilmente a los siete centenares. A continuación, están las españolas, que figuran en el 32 por ciento de los procesos, aunque numéricamente son mucho menos importantes que las indígenas, debido a que las solicitaciones que las afectaban no tenían el carácter masivo de aquéllas. Luego vienen las que la documentación identifica como mestizas, con cerca del 14 por ciento, y cierran la clasificación de las víctimas por grupos étnicos, las mulatas y las negras, con porcentajes que fluctúan entre el 6 y 5 por ciento. 
Las españolas, pareciera que en su gran mayoría eran de baja condición social. Así por lo menos lo reflejaría la escasa información disponible, aunque sobre ese aspecto no estamos en condiciones de efectuar ninguna cuantificación. Pero, algunos indicios que aportan las relaciones de causas, nos llevan a sostener ese planteamiento. Así, cuando se trata de una mujer principal, se destaca expresamente, indicando su condición de noble o de mujer de encomendero ${ }^{104}$. En la inmensa mayoría de las testigos se dice simplemente su condición racial y estado civil y a veces se agrega que es mujer honesta. Pensamos, que de ser ellas nobles se habría dejado constancia en la relación, porque la calidad de los testigos incidía en la sentencia. Además, en tres causas, las solicitadas eran criadas de conventos de monjas y en alguna otra se indica que el marido es un artesano. Si a esas características sociales que se darían en el núcleo español, les agregamos los otros segmentos raciales, tenemos que la víctima por antonomasia fue una mujer perteneciente a los estratos más bajos de la sociedad.

También son muy inseguras las referencias que podamos dar sobre el estado civil de las víctimas. Sólo disponemos de información sobre 112 testigos, lo que representa un volumen más bien pequeño con respecto al total de mujeres involucradas en este delito. Con todo, es posible que esa muestra, que es producto de la arbitrariedad del secretario del Tribunal, refleje alguna tendencia válida. Ahora bien, esos datos nos indican que, a la hora de hacer requerimientos amorosos en la confesión, los sacerdotes no hacían mayores distingos entre solteras y casadas. En todo caso, según la muestra, las primeras significaban el 45 por ciento del total y las segundas el 40 por ciento. A gran distancia, en consecuencia, figuraban las monjas, que representaban poco más del 12 por ciento y la presencia de las viudas era casi nula, pues encontramos referencias sólo de tres. Curiosamente, esta distribución por estado civil, guarda bastante relación con la que se da en la Inquisición de Cuenca, en que aparecen equiparadas las víctimas casadas con las solteras ${ }^{105}$.

De la revisión de las fuentes y de los intentos cuantificadores relacionados con las víctimas, llama la atención el fenómeno de la respuesta de ellas a las proposiciones de los sacerdotes. Por cierto que también en este caso es muy difícil llegar a resultados concluyentes. Pero nuevamente las relaciones de causas nos entregan algunos indicios interesantes. En efecto, disponemos de información referente a las características que revistió la solicitación en un total de 84 causas. En otros términos, sabemos lo que 84 reos dijeron, propusieron, hicieron o intentaron hacer a sus penitentes. Pues bien, de ellos, el 23 13.

${ }^{104}$ Causas de Alonso de Espina y José Mora. AHN, Inqquisición, lib. 1029, f. 99 y leg. 3592, exp.

105 Adelina Sarrión, op. cit., p. 275.

Missionalia Hispanica Hispania Sacra 48 (1996) 
por ciento se limitó a hacer proposiciones deshonestas o a decir algunos requiebros a sus "hijas de confesión"106. Un porcentaje levemente inferior, alrededor del 20 por ciento, además de las palabras y requerimientos amorosos acarició o intentó acariciar a la penitente ${ }^{107}$. Muy pocos, sólo tres sacerdotes fueron acusados de imponer disciplinas a las mujeres que confesaban, dándoselas ellos personalmente, para lo cual procedían a desnudarlas ${ }^{108}$. Hubo más de uno que sin mediar palabra trató de acariciar a sus víctimas, como aconteció con el doctrinero Joan de Valdivieso, denunciado por una india "de que en la cuaresma de 1590 se había ido a confesar con él y le había palpado los pechos sin decirle palabra y luego la había confesado"109. Con todo y esto es lo interesante, el 51 por ciento de estos reos, luego de hacer las proposiciones del caso, consiguió consumar las relaciones sexuales con algunas de las penitentes solicitadas. Muchas veces el acto sexual no se efectuó durante la confesión o en los momentos previos o posteriores a ella, pero allí se pusieron de acuerdo o se dió el consentimiento.

Empero, para no inducir a interpretaciones exageradas, es necesario hacer una precisión con respecto a ese último porcentaje. Por de pronto no significa que la mitad de las mujeres solicitadas hubiesen accedido a los requerimientos del reo. Hay que considerar que cada uno de ellos solicitaba a varias mujeres y sólo algunas de ellas consentían. Pero, visto el fenómeno desde la perspectiva del acusado, es evidente que en un alto porcentaje lograban alcanzar lo que en último término se proponían y más aún considerando que muchas mujeres eran reacias a reconocer que habían tenido tratos con el confesor. Casos como el de Vicente Gómez, que en 1759, confesó haber consumado el acto carnal

$106 \mathrm{Tal}$ es el caso del dominico Pedro de Serpa, que hacia 1593, decía a una de las penitentes que tenía "unos ojos muy lindos y era muy hermosa y que diciendo ella que no la podía ver por' estar el rallo tapado, había respondido que era Zahori", AHN, Inquisición, lib. 1028, f. 285-286. Gabriel Cobeñas, dominico, residente en Santiago de Chile, entre otras acușaciones de que era objeto en 1579 , está la de una mujer casada llamada Gabriela Justiniano que dice "que antes que comenzase la confesión la requirió a conversión lasciva y deshonesta y ella le dijo que dejase aquellas palabras y luego se comenzó a signar y se confesó con él". AHN, Inquisición, lib. 1027, f. 236.

107 Por ejemplo, Gabriel de Migolla, cura de Almaguer,obispado de Popayán, hacia 1580 fue acusado de decir a una mujer "que la quería mucho y la desearía servir, cogiendole las manos y palpándole los pechos". Francisco de Rabanal, de la orden de San Francisco, fue acusado en 1598, entre otras, por una indígena casada de 24 años, de "que habiendo acabado de decir los pecados la tomó de las manos y la abrazó y la dijo que era hermosa y que la quelía mucho". AHN, Inquisición, lib. 1027, $f$. 169 v.; lib. 1028 , f. 558 v. y 604 v.

108 Causas de Baltazar Martínez (1584), Pedro Muñoz(1696) y José Ignacio Gutiérrez(1784). AHN, Inquisición, lib. I027, f. 672v.; tib. 1025, f. 25; leg. 1649-1, exp. 16.

109 AHN, Inquisicion, lib. 1028 f. 532 y 584. 
con alrededor de 20 mujeres o el de Rafael Venegas, que de 10 mujeres a las que solicitó 9 habrían consentido, tampoco son excepcionales ${ }^{110}$.

\section{CAUSALIDAD DEL FENÓMENO}

a) En relación con el sacerdote

A la hora de buscar explicaciones sobre estos impropios comportamientos de los sacerdotes estudiados, previa y necesariamente, hay que insistir en que su significación cuantitativa es escasa, pues el número de solicitantes, que cuando más pudo llegar a dos centenares entre 1570 y 1820 , resulta minúsculo si se tiene en cuenta que en un momento determinado sólo en el distrito de la audiencia de la Lima había alrededor de 5 mil clérigos ${ }^{\prime \prime}$. Con todo, las repercusiones que aquellos hechos tenían para el prestigio del clero en particular y de la religión católica en especial, eran muy negativas, independientes del número de clérigos involucrados. Esto por lo demás explica que haya pasado a ser un delito perseguido por la Inquisición.

Pero ¿por qué a pesar de la gravedad del hecho y de las duras sanciones a las que se exponían, nunca faltaban clérigos que cayeran en estas conductas? Sin duda, la naturaleza humana era el condicionante básico de tales acciones. Con todo, la gran mayoría de los sacerdotes sublimaba o reencausaba los apremios sexuales, aunque había algunos que no lo podían hacer y se desahogaban rompiendo la continencia. Y entre estos últimos había unos pocos que trataban de alcanzar sus objetivos nada menos que utilizando el sacramento de la confesión. ¿Porqué se daba esta última situación? ¿Era ella nada más que un problema de intensidad de los requerimientos fisiológicos, que resultaban imposibles de dominar para algunos? Es evidente que hay mucho de eso y que los apremios son diferentes dependiendo de cada cual. Sin embargo, esa razón resulta insuficiente para explicar la utilización de la penitencia como medio para satisfacer o intentar satisfacer sus apremios. De hecho, tras el comportamiento de los sacerdotes solicitantes había una serie de factores que influían en mayor o menor medida.

\footnotetext{
110 AHN, Inquisición, leg. 1656, exp. I y leg. 2209, NI0; lib. 1031, f. 372, 433 y 472.

"I TAdeo HaËNKE, Descripción del Perú. Imprenta Lucero, Lima 1901. Este cronistn obtiene los datos del clero del censo de 1792 y los señala respecto de cada una de las intendencias que describe. A su vez, Antonio Vázquez de Espinosa (op. cit., p. 623), hacia 1617, estima en 2.982 el número de religiosos existentes en el Perú, pertenecientes a las órdenes de Santo Domingo, San Francisco, San Agustín, La Merced y La Compañía.
}

Missionalia Hispanicn

Hispania Sacra 48 (1996) 
En primer Iugar habría que considerar la falta de vocación de numerosos miembros del clero. Como lo ha demostrado magistralmente Antonio Domínguez Ortiz en sus trabajos sobre el clero en la España del Antiguo Régimen, muchas personas ingresaban a él no por razones vocacionales sino más bien por condicionantes económicas, en último término, para subsistir. Era frecuente que los padres de modestas familias plebeyas, vieran en el sacerdocio de algunos de sus hijos una salida a la angustiosa situación familiar. En otros casos, la temprana colocación de un hijo en un convento era simplemente una fórmula para descargarse de alguna boca excesiva. Los niños ingresaban de muy corta edad a los conventos y ya allí seguían hasta terminar de sacerdotes. En muchos de ellos la vocación nunca estuvo presente, lo cual hacía que les resultara muy difícil el poder sobrellevar las obligaciones que les imponía su condición. Las relaciones de causas del Tribunal de Lima nos entregan uno que otro indicio que apunta en aquel sentido. Así por ejemplo, el jesuita Martín Morante, natural de Piura, había ingresado a la Compañía a los 13 años y Francisco Ramírez, nacido en Lima, lo había hecho a los 16 años ${ }^{12}$. También, figuran varios eclesiásticos de origen mestizo e incluso uno de ellos dice ser hijo natural ${ }^{113}$. La modestia e incluso pobreza familiar queda patente en muchos casos, entre los que se puede citar el de Rafael Venegas, que siendo niño, se desempeñó como criado en una casa en Concepción ${ }^{114}$. Empero, bastante más explícitos resultan los juicios que sobre los eclesiásticos emitía en 1588 el Virrey Conde del Villar: "Los clérigos particulares de este reino son en tres maneras: unos vienen de Castilla y otros se ordenan acá, aunque nacieron en ella, y otros son nacidos y criados en este tierra: a poco de los que vienen de Castilla se entiende que les trae el deseo de servir a Dios sino el de enriquecer, y así los más no cuidan de saber la lengua, sino de las inteligencias y granjerías con que pueden ganar de comer....Los que se ordenan acá de los nacidos en Castilla, regularmente son soldados delincuentes y hombres que por culpa suya se hallan necesitados de ordenarse, aunque también hay quien lo hace por christiandad y devoción...; y los nacidos y ordenados acá aunque suelen ser expertos en la lengua de los indios, pocas veces tienen aprobación de costumbres ni las partes que deben tener los que han de dar pasto espiritual..."115.

Al fenómeno antes comentado debe añadirse el de la falta de formación que caracterizaba a numerosos sacerdotes. Por lo que referido en el apartado pertinente, la ignorancia era la tónica entre los solicitantes, al punto que los poseedores de algún grado académico, detectados, no pasan de ocho. Y los

112 J.T. MEDINA, Inquisición de Lima, op. cit., t. 11, p. 203. AHN, Inquisicion, lib. 1032, f. I18v. 113 AHN, Inquisición, lib. 1032, f. 175.

134 MM. t. 283 , f. 140.

II J.T. MEDINA, La Inquisición en Lina, op. cit., t. II, pp. 408-409. 
que como gran cosa decían tener estudios de gramática, eran descalificados por los inquisidores al destacar que lo poco que habían estudiado lo sabían mal. Es indudable que para un sacerdote sin vocación, ignorante, nústico, resultaba muy difícil controlar sus instintos.

A todo ello debe agregarse la imagen que sectores eclesiásticos y tratadistas de moral tenían de la mujer. Esta era vista como la encarnación de la lujuria. Su cercanía, su hermosura, su mirada, su conversación, resultaba peligroso para el hombre que quisiera mantener la castidad. El jesuita Luis de la Puente, en un tratado escrito en 1625, al referirse a la lujuria y a las advertencias para no ser presa de ella, dice, citando a Salomón, "que la mujer es más amarga que la misma muerte: su vista es lazo, su corazón redes y sus manos cadenas". Más adelante, entre los "avisos" que indica para mantener la castidad, recomienda "no tocar, ni dejarse tocar de mujer alguna, aunque sea por título de piedad, especialmente a solas...porque este tocamiento es como tocar con el fuego, que suele dejar el corazón abrazado"116. Por su parte, Fray Luis de Granada, en 1582, en su Guía de pecadores, daba la siguiente recomendación para combatir la lujuria: "aparta los ojos de la mujer ataviada y no veas su hermosura..., excúsate, cuanto fuere posible, de hablar solo con mujeres de sospechosa edad...Huye, pues, toda sospechosa compañía de mujeres, porque verlas daña los corazones, oirlas los atrae, hablarlas los inflama, tocarlas, los estimula; y finalmente, todo lo de ellas es lazo para los que tratan con ellas..."17.

Esa manera de ver a la mujer, ese temor que despertaba entre los moralistas, también se refleja en el ámbito de la Iglesia peruana, como queda de manifiesto en en edicto del Arzobispo Antonio de Barroeta de 10 de octubre de 1754 referente a la vestimenta de las mujeres. En él se señala: "Y ahora nos ha parecido no de menos indecencia, de vivo incentivo, y de muy grande irreverencia, que traigan el pecho descubierto, particularmente, cuando van a las iglesias, y llegan al comulgatorio, pues con la acción de levantar el manto, para recibir la Sagrada Forma, descubren interioridades, que se presentan a los ojos, por donde el alma se conducen impuros pensamientos. Por tanto, teniendo presente en esta parte lo que muchos sabios y espirituales varones han declamado contra la desnudez de brazos, y pechos, y contra el demasiado adorno en cabeza, y cara del otro sexo, por lo que las Sagradas Letras aconsejan, apartar el rostro de la mujer aliñada cuya artificiosa hermosura ha sido causa, de que muchos perezcan y que la concupiscencia tome pábulo, para encenderse como fuego....mandamos... bajo pena de excomunión mayor... a todas las

\footnotetext{
116 LUIS DE LA PUENTE. Tratado de los estados de continencia y virginidad. En tomo III de Ia Obras Espirituales. Madrid, 1690, pp. 33 y 63. 411 .

117 Fray Luis de Granada, Guía de pecadores. Madrid 1780. Primera parte del libro segundo, p. 
mujeres..., que, así en los templos, como en la calle traigan cubierto el pecho y brazos y que para ello usen paños tupidos y nada transparentes.... de modo que no este expuesto a la vista mas que la cara y esa con todo el recato correspondiente y sin muy prolijo adorno..."118.

Pero esa imagen de la mujer como fruto prohibido, despertaba la imaginación de los hombres, hacía que resultara tremendamente atractivo el develar los misterios que encerraba, sobre todo para algunos de quienes debía ser, por una promesa solemne, un asunto vedado de por vida. Los atractivos de la mujer eran la perdición del hombre, pero al mismo tiempo encerraban toda suerte de placeres, que golpeaban los sentidos y desataban los deseos. El cuerpo femenino, sumergido bajo las telas de los refajos, faldas y mantos, se transforma en una verdadera obsesión para muchos de los solicitantes. Por ejemplo, fray Baltazar Martínez, de la orden de San Francisco, confiesa, en 1584, que imponía disciplinas como penitencia, haciendo que se quitasen la ropa para azotarlas el mismo, y que todo ello lo hacía "por desear ver a una mujer desnuda y holgarse de ello"119. A su vez, el jesuita Francisco Ramírez, en 1667 , les pedía a las penitentes "que se levantasen las faldas para ver la naturaleza por nacen los hombres, pero que fue por curiosidad y ver lo que no había visto"120.

Con todo, los factores antes comentados no nos explican en último término el porqué de la solicitación; en otras palabras, aquéllos son insuficientes para comprender la utilización de Ia penitencia con el objeto de satisfacer apetencias sexuales. Para llegar a entender esos comportamientos es necesario detenerse en el análisis del sacramento de la penitencia, en la orientación que tuvo entre los siglos XVI y XVIII. Lo cierto es que entre los pecados capitales, la lujuria fue el que más concentró la preocupación de los moralistas. Fray Luis de Granada, dice que el buen cristiano debía imponerse el firme propósito de no de hacer cosa alguna que fuese pecado mortal; $y$, al dar algunos ejemplos de hombres de excepción que rechazaron el pecado, menciona el caso de un joven que se cortó la lengua antes de caer en las tentaciones de una mujer; agrega además que "pudiera contar otros (casos), que desnudos se revolcaron entre zarzas y espinas: $y$ otros en medio del invierno entre las pellas de nieve, para refriar los fuegos de la carne atizados por el enemigo". En suma, la lucha

It8 Sínodos de Lina de 1613 y 1636 . Edición de Bartolomé Lobo Guerrero y fernando Arias de Ugarte. Consejo Superior de Investigaciones Científicas. Madrid, 1987, pp. 441-442.

119 AHN, Inquisición, lib. I027, f. 672.

120 Ibid, lib. 1032, f. 118. El interés por el cuerpo femenino que manifiestan los solicitantes queda de manifiesto en diversas relaciones de causas, entre las que pueden citarse las de Juan de Cobeñas, Pedro Pacheco y Alonso de Espina. AHN, Inquisicion, lib. 1027, 89; lib. 1028, f. 528; y lib. 1029, f. 99. 
contra los pecados de la carne, le sirve para mostrar la conducta ideal del buen cristiano frente al pecado en general. Además, al referirse específicamente a la lujuria señala que "es uno de los vicios más generales y más cosarios y más furiosos en acometer, que hay. Porque (como dice San Bernardo) entre todas las batallas de los cristianos, las más duras son las de las de la castidad"121 .

Entre los pecados contra la ley de Dios, los cometidos contra el sexto y el noveno mandamiento también adquirieron en esta época una gran importancia, consagrándole los tratados de moral mucha atención y numerosas páginas. En ellos se entraba a clasificar los tipos y especies de actos, detallándose los más diversos casos y situaciones que podían significar un atentado contra tales preceptos. Así, algunos tratados entraban a distinguir entre los pecados de lujuria imperfectos o no consumados, como pensamientos, abrazos, besos, tactos, fuera del matrimonio, con el ánimo de delectación venérea y sin efusión de semen; y los pecados de lujuria consumada, que a su vez eran clasificados en intra naturam y contra naturam. En cada uno de ellos se indicaban las diversas especies, con las situaciones que podrían darse y con la gravedad de la falta que ellas implicaban.

En la medida que los pecados sexuales adquirieron esa importancia, la confesión, que era la instancia para purgarlos y obtener el perdón, tendió a centrarse en gran medida en esas materias. Así por lo demás lo reconoce en el siglo XVIII San Alfonso María de Ligorio, que señala que este vicio (el de la lujuria) es la materia más frecuente y copiosa de las confesiones ${ }^{122}$. Y lo confirman autores modernos que han efectuado estudios específicos sobre el particular, como Michel Foucault, quien expresa que "el sexo fue tema privilegiado de confesión"123. En torno a ella se generará todo un "discurso" sobre la materia y dicho sacramento pasará a ser la instancia por antonomasia donde se hable de sexo. Jean Delumeau, sostiene que desde comienzos de los Tiempos Modemos, la lujuria y los pecados de la carne pasarán a ocupar un lugar preponderante entre los tratados referentes a la confesión y cita una obra anónima de la década de 1490 que enseña que la fornicación es un pecado más detestable que el homicidio o el robo ${ }^{24}$.

Como hemos señalado al referirnos al sacramento de la penitencia, la obligatoriedad anual del sacramento, fomentó la aparición de sumas y manuales para uso de los confesores, aunque las primeras fueron perdiendo ese carácter

\footnotetext{
121 FRAY LUIS DE GRANADA, Giía de pecadores, op. cit., pp. 385 y 405

122 Alphonsi MARJAe de LIGORIO, Theologia Moralis. Romie, 1905, t. I, p. 666, No 413.

123 Michel Foucault, Historia de la sexualidad. Siglo veintiuno editores. Madrid, 1984, t. I. p. 77.

124 JeAN DELUMEAU, Le péché et la peur: La culpabilisation en Occiden (XHI-XVHI siècles). Fayard. Parśs, 1983, p. 238.
}

Missionalia Hispanica

Hispania Sacra 48 (1996) 
con el tiempo, para transformarse en obras de derecho canónico. Pero los manuales mantuvieron el sentido primitivo de cumplir un fin didáctico, al ensenar al sacerdote como administrar la penitencia y al fiel como recibir el sacramento $^{125}$. En España se editaron numerosas de estas obras y ellas llegaron a América y se encontraban en las bibliotecas de los eclesiásticos y de los conventos ${ }^{126}$. Pues bien, el contenido de estos manuales es muy explicito cuando se refieren al sexto mandamiento y muchos, utilizando el sistema de preguntas y respuestas, recomendaban a los confesores unos interrogatorios exhaustivos sobre todas las posibilidades de pecado en relación con el sexo. Así, Joseph Gavarri daba las siguientes recomendaciones al confesor: "Procure también preguntar a los hombres y en particular a los mozos, las veces que desearon pecar con mujeres, por los meses, porque suelen pecar muchísimo y con esto los dirán todos... Tal vez llegará alguna mujer que le dirá que no puede retener el semen de su marido intra vas en el acto matrimonial y así si podrá con este defecto pagarle el débito. Responderale que sí. Otra le dirá que sabe que su marido suele no consumar la cópula, ne se quatur generatio, y que el tal tiene después polución fuera de su vaso; y así que no obstante esto, si le pagará el debito? Responderale también que sí, como no consienta..."127. Como se ha indicado, los manuales no sólo estaban destinados a los sacerdotes, sino también a los penitentes, con el objeto de que efectuaran una más perfecta confesión. Incluso se escribían obras destinadas de manera específica a los pecadores, para orientarlos en su examen de conciencia. Fray Tomás Navarro escribió una de ellas en el siglo XVIII y en una de sus partes decía: "Examine V.M. si se mezcló con alguna mujer, si estando con ella impidió la generación humana, de cualquier modo que fuera, o si se expuso a riesgo grave próximo; debiendo advertir si era casada, soltera, vir-

\footnotetext{
12, Ibid, pp. 223-225.

126 Varios de esos manuales se encontraban en Chile en hs bibliotecas de los obispos Marín, Bravo del Rivero y Alday, entre otros. También estaban algunos en la biblioteca del obispo de Buenos Aires, Azamor y Ramírez. La mayoría de los que nosotros hemos revisado pertenecían al convento de los jesuitas de Santiago de Chile.

127 Fr. JoSEPH GAVARR, "Instrucciones para predicadere. y confesores. Madrid, 1679, pp. 137 138. El padre Pedro de Calatayud, a mediados del siglo XVII, en su Modo práctico y fácil de hacer una confesión general, señalaba en lo que respecta al sexto mandamiento: "Se puede ir preguntando: $l^{\circ}$ por los pecados de obras; $2^{\circ}$ por los tocamientos feos; $3^{\circ}$ por las palabras; $4^{\circ}$ por los pensamientos, previniendo, que los pecados que se cometieron contra este mandamiento por persona o con persona casada, consagrada, parienta o de un mismo sexo, han de ir aparte. Dime: has vivido amancebado? Sf Padre; con dos personas. ¿Eran casadas o solteras? Una era casada y otra soltera. ¿Estaban en casa o fuera? La casada estaba fuera; la soltera en casa. ¿Cuanto tiempo viviste amancebado con ellas? Con

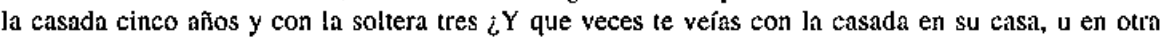
parte? Una semana con otra, serían cuatro veces. ¿Y siempre que ibas a su casa o te vefas con ella, caíns de obra? Siempre, no; porque no habín ocasión; serín la mitad o tercia parte de las veces, aunque casi siempre llevaba el ánimo dispuesto para ello...". Edición de Madrid, de 1816, pp. 50-57.
} 
gen, pariente, o si tiene voto de castidad ... Examine, si aunque no tuviera cópula, tuvo tactos torpes de pechos, partes vergonzosas, o de manos y si al mismo tiempo tuvo deseo de comercio sucio. Examine, si aunque no la tocara, la miró con deleite o con peligro próximo de ello, ora fuera la cara, manos, pechos, u otras cosas; y si de esto, o de lo que se acabó de decir se siguió alteración en la carne, con efusión de materia, que sirve a la generación, o con peligro grave próximo de ello"128.

En América también se publicaron numerosos confesionarios, que eran equivalentes a los manuales peninsulares y que por lo tanto pretendían servir de guías a los sacerdotes en la administración de los sacramentos y en la instrucción a los fieles. Varios de ellos estaban escritos de manera específica para facilitar la administración del sacramento en los indígenas, aunque en el caso de México, predominaban los manuales para los fieles en general ${ }^{129}$. En Perú, en cambio, pareciera que la edición de confesionarios fue más limitada y los pocos que se publicaron estuvieron orientados a la población aborigen ${ }^{130}$.

128 Fr. THOMÁs NAVARRO, Consulta espiritual en lo que un pecador serdaderamente arrepenti. do propone con deseo de acertar, el infeliz estado de su alma para una buena confesión general. Gerona, 1771, p. 163.

129 Para el caso mexicano, han sido trabajados por Asunción Lavtin en su artículo "La sexualidad en el México colonial: un dilema para la Iglesia", que forma parte del libro, Sexualidad y matrimonio en la América hispánica. Siglos XVI-XVIII, coordinadora Asunción Lavrin. Grijalbo, México, 1991. Entre los confesionarios publicados en México podrían mencionarse el de Felipe Zúñiga y Ontiveros, Cinco circunstancias de una buena confesión y método de examinar para ella la conciencia, México, 1798; y el de Gabino Carta, Práctica de confesores: Práctica de administrar los sacramentos, en especial de ta penitencia, México, 1653. En este último, al tratar del sexto mandamiento se hace una clasificación detallada de las siete especies de lujuria: fornicación simple, adulterio, incesto, estupro, rapto, sacrilegio y pecado contra naturam, que son todos pecados mortales. $Y$ al referirse a esta última dice: "La séptima especie de lujuria es pecado contra natura y se divide en varios modos: mallicie o polución voluntaria, sodomía y bestialidad...(más adelante agrega) Otro pecado contra naturam, es sodomía, vicio nefando, es juntarse deshonestamente dos personas de un mismo sexo, hombre con hombre, o mujer con mujer; y también se reduce a sodomía entre y mujer in vase proepostero y aunque sea marido y mujer es pecado mortal gravísimo. En este pecado dcbe explicar en la confesión la cualidad de la persona con quien peca, si es casada, o si tiene voto de castidad o si es pariente", op. cit., p. 66.

134 Con respecto al Perú, podemos citar el Confessionario para los curas de indios. Con la instrucción contra sus Ritos: y exhortación para ayudar a bien morir. Por autoridad del Concilio Provincial de Lima, 1583; el de Ludovico Bertonio, Confessionario muy copioso en dos lenguas, Amara y Española, con una instrucción acerca de los siete sacramentos de la Sancta Jglesia y otras varias cosas, Lima 1612; y el de Ivón Pérez Bocanegra, Ritual, formulario e Instrucción de Curas para administrar a los naturales de este reino los santos sacramentos del bautismo, confirmación. eucaristía y viático, penitencia, extremaunción y matrinonio, Lima, 1631. El padre Luis de Valdivia public6 en Lima, en 1606 y 1607 , tres textos sobre la lengua de los indios de Chile y Cuyo, que contenían además un catecismo y un confesonario. En eșta última parte se detenía de manera especial en precisar los casos en que se transgredía el sexto mandamiento. Én relación con él se incluyen las siguientes preguntas: 1. ¿has pecado con alguna mujer? ¿Con cuántas? ¿Cuántas veces? 2. ¿Era

Missionalia Hispanica

Hispania Sacra 48 (1996) 
Aunque esos manuales fueran desconocidos para muchos sacerdotes, es evidente que marcan un determinado estilo y orientación con respecto al sacramento de la penitencia, que se transmitía no sólo a través de esas obras sino también por otros medios. Debe tenerse presente que, para poder confesar, los sacerdotes requerían de una licencia especial otorgada por el ordinario. El Primer Concilio Limense de 1551-1552, lo estableció así en la constitución 66, siguiendo en esa materia lo dispuesto por el concilio de Trento. Aún más, para obtener esa licencia, los clérigos y religiosos debían rendir un examen, que, según el Tercer Concilio Limense, además permitiría distinguir entre aquellos que estaban en condiciones de confesar a cualquier persona y quienes, por ser menos doctos, debían tener una limitación en cuanto a personas y estados. Esas pruebas, que, entre otras materias, debian medir la capacidad para ponderar la gravedad de los pecados y sus penas, lógicamente tendían a uniformar los criterios con respecto al sacramento, al mismo tiempo que marcaban una determinada tendencia en la forma de administrarlo, que estuvo influida por los autores que trataron sobre la materia.

En definitiva, era normal para la época que, en la confesión, los penitentes fuesen sometidos a minuciosos interrogatorios sobre aspectos relacionados con el pecado de lujuria. Para determinados sacerdotes, resultaba relativamente fácil, por lo tanto, sobrepasar el margen de lo conveniente en las preguntas, a instancias de sus debilidades y del ambiente que podía generarse en la confesión. Las relaciones de causas, algo nos dejan entrever al respecto. Por ejemplo, el clérigo Hernando de Espinar fue acusado en 1583 de preguntar a una muchacha "si se miraba los brazos y las piernas y las partes vergonzo-

casada esa mujer o soltera? ${ }_{i} \mathrm{Y}$ cuantas veces la conociste? 3 . ¿Tienes alguna manceba contigo? ¿Cuántos días la has tenido? 4. ¿Has pecado con atguna doncella? ¿Corrompístela? 5. ¿Has forzado alguna mujer para pecar? 6. ¿Has emborrachado a alguna mujer para pecar con ella? 7. ¿Has pecado con parienta tuya, o de tu mujer, o con dos hermanas, o con madre e bija? ¿Cuántas veces? 8 . ¿Has abrazado o besado alguna mujer, o retozado de otra manera? 9. ¿Has pecado con mujer infiel? 10. ¿Has hecho algún pecado de estos en la lglesia, que es casa de Dios? ¿O en el cementerio que está junto a fa Iglesia? 11. ¿Has hablado palabras deshonestas, o cantádolas? 12. ¿Has sido alcahuete de algunos? $¿$ Cuántas veces? ¿Era mujer casada, o hombre casado a quien fuiste enviado, o quien te envió? 13. ¿Has tenido alguna polución voluntaria estando despierto? ¿Cuántas veces? 14. ¿Has pecado con otro varón como tú? $i \mathrm{O}$ con algún carnero, caballo, o perro o con otro animal, o con otra cosa? ¿Cuántas veces? Citado por Horacio Zapater, La búsqueda de la paz en la guerra de Arauco: Padre Luis de Valdivia. Editorial Andrés Bello. Santiago, 1992, p. 104, La versión publicada en Lima en 1606 bajo el título de Confessionario breve en la lengua del reyno de Chile, difiere en la redacción de las preguntas del cuestionario, con respecto a la transcrita por Zapater, aunque el sentido es muy similar. La versión de 1606 contiene 22 preguntas sobre el sexto mandamiento y es el que genera el mayor número de interrogantes. Con todo, en el texto se advierte al sacerdote respecto a la actitud que en esas circunstancias debía tener con las mujeres; específicamente recomienda que se les hagan las preguntas "acomodadas a las personas, y no se ha de preguntar de lo dicho, más de lo probablemente se entiende que habrá hecho el que se confiesa"( $\rho p$. cit., p. 10). 
sas...., y enojada la dicha doncella de que se le hiciesen aquellas preguntas.... el padre le dijo que no tenía de que enojarse que eran preguntas que se preguntaban". A otra joven le preguntó "si tomaba gusto o si se ejercitaba en traerse las manos por las carnes y tomarse los pechos y por las partes vergonzosas..."131. A su vez, el jesuita Francisco Ramírez, fue acusado de preguntar a una mujer casada "que cómo eran los actos carnales que tenía con su marido y le decía que no había de ser más que un acto por cumplir con la obligación y sin usos de posturas extraordinarias sin embargo de ser su marido..." 132 .

Otro aspecto importante relacionado con la confesión, tenía que ver con el entorno en el cual muchas veces ella se llevaba a cabo. Por lo general, los templos permanecían en la penumbra y las confesiones se efectuaban en los sectores más apartados o aislados, como capillas o sacristías. Además, como en parte se desprende de la documentación, la existencia de confesonarios, que separan al sacerdote del penitente no eran de uso general e incluso existían algunos, que, por sus dimensiones, permitían que ambos estuvieran en su interior $^{133}$. A eso debe agregarse que con cierta frecuencia se utilizaban como lugares de confesión los claustro y celdas de los conventos, las capillas y sacristías, las casas particulares de los clérigos e incluso de las casas de las penitentes. Por lo general esto último ocurría cuando una hija de confesión de un sacerdote se encontraba enferma. Pues bien, varios casos de solicitación vistos por el Tribunal de Lima se produjeron en las casas de las penitentes. Allí, el sacerdote para efectuar la confesión tendía a cerrar la puerta de la habitación, por lo que quedaba a solas con la penitente, que se encontraba en cama, a veces con muy escasa ropa bajo las sábanas ${ }^{134}$.

En consecuencia, en un ambiente con esas características, se producía ese especial y físicamente muy cercano encuentro entre el eclesiástico y la mujer, con la connotación ya comentada, en el que, entre otras materias, se hablaba de sexo, lo que muchas veces le permitía a aquél enterarse de las debilidades de la penitente. Para aquellos sacerdotes con escasa vocación, sin principios ni formación sólida, puestos en esas circunstancias, resultaba tentadora y muy difícil de rechazar la posible inclinación a dejarse llevar por las pasiones.

\footnotetext{
131 AHN, Inquisición, lib. 1027, f.285-289.

132 Ibid, lib. 1032, f. 118 . En la causa de Frny Andrés de Argijello, seguida en 1587, también, hay evidencias de estos interrogatorios sobre el pecado de lujuria que caían en un ámbito reprobable. AHN, Inquisición, lib. 1028, f. 103 v.

${ }^{133}$ En la causa de Joan Leiva, uлa mujer mestiza dice que "entró en el confesonario y el padre la tomó por la cintura y la dijo que no la había de confesar... y queriéndose salir de allí, la tuvo y rasgó el manto y la forzó en el confesonario teniendo acceso carnal con ella". AHN, Inquisición, lib. I032,

134 AHN, Inquisición, Jib 1027, f. 285, causa de Hernando de Espinar. También causa de Lorenzo López. AHN, Inquisición, lib. 1028, f. 301 .
} f. 38 . 
El otro aspecto, que no puede dejar de considerarse es que este era un sacramento de administración masiva, por su periodicidad y porque involucraba a la totalidad de los fieles. Todas las personas con discernimiento debían confesarse obligatoriamente por lo menos una vez al año, de preferencia durante la Cuaresma o la Semana Santa, y la autoridades eclesiásticas y los clérigos se encargaban de velar por el cumplimiento de esa disposición. De acuerdo con lo establecido por el Primer Concilio Limense de 1551-1552, los curas debían hacer padrones de todas las personas que estaban en edad de confesarse. Para ello tenían que matricular a todos "los vecinos e moradores, estantes y habitantes" de sus parroquias y del distrito anexo a su cargo, sin dejar persona alguna sin considerar, "desde los principales de casa e hijos e criados de casa e del campo hasta los individuos cristianos y esclavos cristianos que tienen en sus casas y haciendas y heredades, asentando asimismo los que están casados". Los curas, además, debían amonestar a sus parroquianos para que cumplieran con el sacramento de la penitencia, señalando al mismo tiempo "las casas que se han de venir a confesar aquella semana, repartiéndolos de suerte que en toda la Cuaresma y Semana de Pascua se puedan confesar to$\operatorname{dos}^{\prime \prime} 135$.

Tales instrucciones no quedaban en el papel, como lo demuestra un proceso seguido por el Tribunal de Lima en 1571 contra el labrador Diego de Arenas. En la relación de esa causa se señala: "sobre que pidiéndole su cura la cédula de confesado él y su casa porque si no la haya le pondría en la tablilla de los descomulgados respondió que no se le daba tres cuartos por aquella excomunión o tres castanetas. Hízose proceso contra él, sin captura, y pareció por el que el dicho reo le respondió que estaba ya confesado él y toda su casa y que traería la cédula...., y que este reo es hombre de campo y de poco entendimiento..."136.

Pero todavía más, pareciera que muchos fieles no se limitaban a confesarse una vez al año, sino que, en la medida que se fue extendiendo la costumbre de la comunión frecuente después del Concilio de Trento, to propio aconteció con la confesión, pues si con posterioridad a ésta, el penitente había incurrido en pecado mortal, estaba obligado a confesarse antes de una nueva comunión. En el Perú, habrian sido los jesuitas, desde su llegada en 1570, los que procuraron introducir la frecuencia de la confesión, que hasta esa época se limitaba a la Cuaresma. La práctica, al parecer se extendió con rapidez a los indígenas, los que habrían mostrado un interés especial por recibir el sacramento, como lo dan entender algunas cartas de miembros de la Compañía escritas por esos

135 Primer Concilio Limense, constitución 66. Rubén Vargas Ugarte, op. cit.

$136 \mathrm{AHN}$, Inquisición, lib. 1027, f. 30. 
años ${ }^{137}$. Además, todo parece indicar que fueron las mujeres las que demostraron especial predilección por reiterar dicho sacramento ${ }^{138}$. Es posible que los exagerados escrúpulos de algunas penitentes y el incentivo por parte de los directores espirituales, expliquen aquel comportamiento, que lleva a un incremento muy importante en el número de las confesiones efectuadas a mujeres. Tal situación habría incidido en el incremento del delito, tanto por una mera cuestión de proporciones, como por el hecho de que un sacerdote llegaba a tener un contacto más frecuente con determinadas penitentes, lo que le permitía un mejor conocimiento de ellas y un grado de familiaridad en el trato que podía inducirlo a efectuar las proposiciones deshonestas ${ }^{139}$.

\section{b) En relación con la mujer}

Como lo hemos indicado, llama la atención la cantidad de mujeres que terminan por consentir a las proposiciones de los sacerdotes, sobre todo si se considera que en estos casos no había de por medio, ni podía haber, ninguna promesa de matrimonio. Como lo ha señalado Jean-Louis Fladrin para el caso europeo y Pablo Rodríguez y Asunción Lavrin para la América hispana ${ }^{140}$, la promesa de matrimonio era uno de los elementos importantes en el proceso de la seducción, que lleva a que la mujer acepte los requerimiento sexuales del galán. El delito de solicitación deja en evidencia que eran numerosas las mujeres solteras que tenían relaciones con los sacerdotes, pero, un porcentaje más o menos similar de casadas hacía otro tanto, con lo que el adulterio es una realidad significativa.

Para tratar de entender esa situación tan especial, hay que considerar la significación que tenía el sacerdote en la sociedad de esa época. De hecho,

137 Fernando de Armas Medina, Cristianización del Perú (1532-/600). Escuela de Estudios Hispano-Americanos. Sevilla, 1953, p. 326.

138 La causa de Joan de Cobeñas deja en claro que algunas de las testigos se confesaban con cierta frecuencia con el reo. MM, t. 280, f. 151 y ss. Esa es por lo demás la opinión de Stephen Haliczer, que atribuye gran imponancia en el desarrollo del delito en la península, al aumento de las confesiones por la reiteración del sacramento que hacen las mujeres.

139 En la misma causa de Joan de Cobeñas queda en evidencia, tanto de las declaraciones de algunas testigos como del reo, que existía bastante familiaridad en el trato entre el sacerdote y algunas de sus hijas de confesión, con las que conversaba y hacía bromas antes y después de la administración del sacramento. Ver al respecto las testificaciones de Ginebra Justinino y Ana de Morales. MM, t. 280, f. 158 y ss.

140 JEAN-LOUSS FALDRIN, "Matrimonio tardio y vida sexual". En La moral sextal en occidente. Juan Granica Ediciones. Barcelona, 1984, p. 326. Pablo Rodríguez, "Promesa, seducción y matrimonio en Antioquía colonial". En Seducción, amancebamiento y abandono en la colonia. Bogotá, 1991, pp. 62-64. Asunción Lavrin, Sexualidad y matrimonio en la Antérica hispánica, op. cit, p. 19.

Missionalia Hispanica

Hispania Sacra 48 (1996) 
era una autoridad, una importante autoridad, con un enorme poder en los más diversos ámbitos y que debía ser escuchada y obedecida. Las propias autoridades eclesiásticas se encargaban de resaltar las funciones que desempeñaba, equivalentes a las de un médico y un juez, al mismo tiempo. Esa autoridad se veía acrecentada en el caso de sus relaciones con el mundo indígena, puesto que el doctrinero y el encomendero constituían los lazos fundamentales con la sociedad española. Esta, en gran medida, ejercía su control e influencia sobre Ios indígenas a través de esas dos instancias.

No podía ser fácil para la mujer, ya fuese española o india, negarse a los requerimientos de un sacerdote, dada la imagen y poder efectivo que tenía. Pero además, este utilizaba diversos argumentos para convencer a las penitentes, que por lo general eran mujeres muy ignorantes. De las relaciones de causas se desprende, que con mucha frecuencia les decían "que no era pecado hacerlo con un fraile"; que las caricias no eran hechas con mala intención; que si lo hacían con otra persona, con mayor razón debían hacerlo con un sacerdote, que era una persona especial. En este aspecto es interesante la razón dada por Fray Alonso Díaz para convencer a una indígena: "que él era Viracocha padre" 141 . Además, muchas veces trataban de tranquilizarlas manifestándoles que no se preocuparan de nada porque el mismo les daría la absolución. También, con frecuencia ocurría que las mujeres solicitadas eran hijas espirituales del confesor. Este, al tener el carácter de padre espiritual, adquiría una gran influencia sobre las mujeres a las que orientaba y no sólo sobre materias de fe. La Iglesia fomentó el desarrollo de esta forma de dirección espiritual por considerar que poseía numerosas ventajas para los fieles; pero, por otra parte tuvo el inconveniente de favorecer la actuación de los curas solicitantes, al permitirles ejercer un poder considerable sobre sus "hijas", que las dejaba bastante indefensas y que a ellos los impulsaba a propasarse.

Lo que podía significar la autoridad de un sacerdote para un penitente queda muy bien reflejado en la declaración de Melchora Uturbey, española, de 34 años, natural de Córdoba, que en 1813 denunció al franciscano Miguel Sar, obligada por otro confesor. En esa oportunidad, al preguntársele sobre los remordimientos de conciencia que los hechos narrados podían producirle, manifestó " que sí tenía, pero que lo deponía unas veces diciendo que mediante que su confesor le mandaba sabría lo que hacía, otras veces que le afligía su conciencia, no se atrevía a ir a otro confesor, porque el dicho su confesor Fray Miguel del Sar, le mandó no se confesase con otro..."142.

141 AHN, Inquisición, lib. 1028, f. 531 y y 599.

${ }_{142}$ Citado por Marcela Aspell de Yanzi Ferreira, "Los comisarios del Tribunal del Santo Oficio de la Inquisición en Córdoba del Tucumán- La solicitación en el siglo XVIII". En Cuadernos de Historia, $\mathrm{N}^{\circ} 4$. Córdoba, Argentina, p. 153. 
Pero además, como lo hemos señalado al pasar en páginas anteriores, a veces los solicitantes tendían a utilizar para sus aviesos objetivos el conocimiento que, merced a la confesión, adquirían de las debilidades de sus penitentes. Los testimonios documentales muestran como en diversas oportunidades los sacerdotes, al enterarse de los pecados contra el sexto y noveno mandamiento de sus feligreses, procedían a hacerles insinuaciones o propuestas descaradas para que hiciesen lo mismo con ellos. Precisamente de utilizar ese recurso acusa el fiscal a Rafael Venegas, en 1658, señalando al respecto: "y que con las noticias que tomó (mediante el sacramento) de las flaquezas y caídas de las mujeres penitentes, le fueron al reo ocasión y aliento para inducirlas a que con él las cometiesen..." ${ }^{143}$.

En consecuencia, el tipo de presiones que sufrían las mujeres solicitadas era muy variado, pues además de los indicados, los solicitantes con frecuencia las tentaban ofreciéndoles regalos de diversa naturaleza e incluso la posibilidad de mantención, como a una querida. Para apreciar la significación que esas promesas podían haber tenido, debe considerarse que numerosas víctimas eran indígenas y, en general, mujeres bastante pobres. El asegurarse la subsistencia, transformándose en manceba de un sacerdote, no resultaba por lo tanto una situación descabellada. En los procesos encontramos varios casos, en que las testigos reconocen mantener un "ilícita amistad" con el acusado por largo tiempo. El citado Rafael Venegas le regaló a una mujer casada, con quien tenía relaciones, un pañuelo de Cambrai, unas medias de seda, 4 varas de ruan, un poco de tafetán naranjado para forrar un jubón y algunos dineros, en diferentes ocasiones, aunque en poca cantidad ${ }^{144}$. El franciscano Francisco Rabanal, en 1599, fue acusado, entre otras cosas, de intentar persuadir a una indígena regalándole un peine y una gargantilla ${ }^{145}$. Otros ofrecían vestidos o dine$\mathrm{ro}^{146}$. Y en no pocas ocasiones, si todas las proposiciones fracasaban, algunos recurrían a las amenazas e incluso a la violencia física. Tal es el caso del propio Francisco Rabanal, a quien también acusan, con respecto a una indígena casada, de que "por la fuerza la metió allá dentro y tubo cuenta con ella por fuerza". Algo parecido ocurre con el doctrinero Pedro de Victoria, que fue denunciado por una mestiza de haber sido introducida por la fuerza en un apo-

143 MM, t. 283, f. 193. En las causas de Pedro Coronado, Matheo de Alvarado y Pedro de Peñaloza, también quedan muy en claro situaciones similares. AHN, Inquisición, lib. 1027, f. 459-561; lib. 1028, f. 558; y lib. 1032, f. 475.

144 MM, t. 283, f. 19. El mercedario Joan de Ocampos, en 1598 era acusado de tratar de convencer a una india a tener tratos deshonestos en los siguientes términos: "yo te regalaré y miraré por ti". AHN, Inquisicion, lib. 1028, f. 558.

145 AHN, lnquisición, lib. 1028, f. 558v.

146 Causas de Andrés Corral, Lorenzo Lopez, Pedro de Villagra y Diego de Sanabria. AHN, Inquisicion, lib. 1028 , f. 301; lib. 1029, fs, 79, 89 y 195 . 
sento y "echada sobre la cama y pretendido tener parte con ella y se había defendido y que por esto la había maltratado y aporreado"147. También deja en evidencia una situación similar, la causa del franciscano Antonio de la Oliva, de Mizque, en Tucumán, a quien una india de 23 años acusó de "que en la confesión la tomó de las manos y la dijo si quería tener cuenta con él y la tentó los pechos y le puso la mano debajo del vestido y la quiso tentar las vergüenzas... y la dicha mujer se puso a llorar y él la halagaba diciéndola que no le temiese que él la quería mucho porque era muy hermosa y la trataría muy bien y la daría muchas cosas... y teniéndola de la mano le decía que si no viniese cuando la llamase le había de azotar, trasquilar y castigar mucho y que él había de estar siempre en aquella doctrina y si no hacía lo que él la decía la había de azotar siempre en la doctrina y la estuvo amenazando mucho y poniendo miedo y por liberarse del le dijo la dicha mujer que se vendría y así la soltó y le dijo mira que te estes en tu casa que yo te enviaré a llamar después y a la noche envió por ella y no queriendo yenir la arrebataron.... y le dijo que se acostara con él y porque no queriendo la amenazó... y echó a la cama (ilegible) la boca con las manos y en fuerza tuvo cuenta con ella y la corrompió....trató carnalmente con ella tiempo de tres meses"148.

Hemos visto que un alto porcentaje de las solicitadas eran casadas y muchas de ellas terminaban aceptando los requerimientos del sacerdote. Sin descartar las presiones que pudieron recibir, también habría que considerar la posibilidad de que en algunos casos la respuesta positiva de las mujeres obedeciera al deseo de alcanzar el placer sexual que la relación matrimonial no les otorgaba. Como bien señala Jean-Louis Fladrin, buena parte de las relaciones extraconyugales se explicaría porque la sexualidad del matrimonio era en gran medida una obligación impuesta por el contrato ${ }^{149}$. Es difícil poder encontrar testimonios que demuestren aquel objetivo en la acción de la mujer. Con todo, así como las relaciones nos muestran las quejas de muchas mujeres, también dejan traslucir que otras aceptaron los requerimientos sin mayor cuestión y que algunas incluso estuvieron dispuestas a participar de manera activa en el juego amoroso. No faltan algunos casos en que el confesor y la penitente terminan acariciándose mutuamente, sin llegar a culminar las rela-

147 AHN, Inquisición, lib. 1028, f. 541v.

148 AHN, Inquisición, lib. 1028, f. 532; 558v. y 601 , El reo reconoció varias solicitaciones y el haber mantenido relaciones ilícitas con diversas mujeres, incluida una india con la cual convivio 6 meses, que no era la misma de la denuncia citada. Fue condenado por el Tribunal en 1599 a abjurar de levi, y se le prohibió confesar mujeres a perpetuidad, al tiempo que era desterrado de la gobernación del Tucumán.

149 JEAN-LOUIS FLANDRin, La moral op. cit., II parte, "La moral sexual y comercio conyugal". 
ciones sólo por los inconvenientes impuestos por el lugariso. En cuanto a las mujeres solteras, habría también que considerar que muchas eran indígenas, por lo tanto su actitud respecto al matrimonio y a las relaciones sexuales era más libre. Lo mismo podría decirse de buena parte de las demás solteras solicitadas, en la medida que pertenecían a los estratos sociales más bajos donde la permisividad sexual era mayor, entre otros factores por falta de control paterno ${ }^{151}$.

En suma, la receptividad de las mujeres a las solicitaciones estuvo muy condicionada por lo que implicaba la figura del sacerdote, por la influencia y poder que tenía especialmente sobre sus hijas de confesión. Más allá del prestigio unido a la investidura sacerdotal, el solicitante podía recurrir a la información sobre la vida íntima de las penitentes e incluso al uso de la violencia, la cual no fue una práctica del todo infrecuente. Pero también, hay que considerar la posibilidad de que muchas mujeres aceptaran las proposiciones atraídas por las perspectivas de obtener un placer que por otras vías no se alcanzaba. Con todo, tampoco se puede perder de vista que, como pareciera desprenderse de las relaciones, la mayoría de las solicitadas rechazó de plano las propuestas del solicitante y que algunas, profundamente escandalizadas, lo hicieron con gran indignación ${ }^{152}$.

\section{CONCLUSIONES}

El delito de solicitación quedó bajo la jurisdicción inquisitorial debido a los temores a la posible propagación de la Reforma Protestante, que había cuestionado el carácter sacramental de la penitencia. En estricto sentido la solicitación no era una herejía, ni los solicitantes podían ser considerados unos herejes. Sin embargo, las autoridades pontificias estimaron conveniente entregar el conocimiento de esas causas a la Inquisición española para evitar de manera más eficaz la perpetración de un delito que podía desprestigiar grave-

150 Rafuel Venegas, entre otras, solicitó a una mujer casada, con la cual se acarició en el confesonario y a la que recibió en la noche en el colegio donde residía. AHN, Inquisicion, lib. 1031, f. 372. Las caricias mutuas también quedan de manifiesto en las causas de Gabriel Migolla y de Pedro Pacheco, aunque en este último caso se trata de una monja. AHN, Inquisición, lib. 1027, f. 169v. y lib. 1028 , f. 528v.

151 Pabjo Rodríguez, op. cit., p. 64.

152 No obstante lo expresado, la fuente, en este punto, nos ofrece algunas dudas respecto a su fiabilidad. Las mujeres tendían a hacer que toda la responsabilidad cayera sobre el sacerdote, incluso en aquellos casos en que había existido una relación intima durante un tiempo largo. Es imposible saber si la declaración de la testigo en que decía haber rechazado la insinuación era verdad. A veces se ofrecen algunas dudas, por la forma como culminaron muchas de esas solicitaciones: con una entrega total de la penitente.

Missionalia Hispanica

Hispania Sacra 48 (1996) 
mente a la religión y a la Iglesia. El fundamento que se dio para justificar esa medida consistió en afirmar que los sacerdotes, al cometer ese delito, sentían mal del sacramento de la penitencia y por lo tanto eran sospechosos de herejía.

La Santa Sede a través de diversas bulas precisará el ámbito exacto del delito y regulará el procedimiento que se debía aplicar en las causas correspondientes. Por lo general, las pautas que entrega el pontificado responden a los requerimientos específicos de la Inquisición española. Casi siempre las bulas se dictaron a instancias del Santo Oficio, salvo en 1622, cuando se le entregó la jurisdicción de manera copulativa con los obispos, generándose un desencuentro por un corto período, hasta que se aclaró la situación de acuerdo a los intereses inquisitoriales. En un caso específico, la disposición de la Santa Sede se originó en una inquietud que se les presentó a los inquisidores de $\mathrm{Li}$ ma, que hicieron llegar a la Suprema. Esta resolvió el punto, que se refería al procesamiento de los que solicitaban a hombres, y a continuación siguiendo una práctica anterior, obtuvo que la Santa Sede confirmara su decisión con una bula.

El procedimiento que se diseñó para las causas de solicitación, en ciertos aspectos se alejaba del modo de proceder en la causas generales de inquisición. La razón de ello era muy simple, había que evitar el escándalo y al mismo tiempo castigar con rigor a los delincuentes para que sirviera de escarmiento. En consecuencia, los reos por este delito no salían en auto público ni privado de fe y durante un tiempo la solicitación quedó fuera de los edictos de fe. Por la distancia del Tribunal con la metrópoli, se le permitió seguir los procesos hasta la definitiva sin tener que consultar a la Suprema. Y, después de unas vacilaciones iniciales, se aceptará el testimonio de las indígenas, no obstante la desconfianza que a los inquisidores les merecian sus dichos. Las penas establecidas para sancionar a estos delincuentes fueron muy rigurosas y el Tribunal de Lima normalmente respetó lo establecido al respecto, salvo en contadas ocasiones, en que la Suprema reprendió a los inquisidores y modificó sentencias. La prohibición de confesar mujeres y hombres a perpetuidad era una sanción extremadamente dura para un eclesiástico, pues lo imposibilitaba de tener acceso a algún beneficio, con lo que se le suscitaban graves problemas de subsistencia. Los clérigos regulares, en ese aspecto no tenían problema, pero sufrían una humillación profunda y permanente ante su comunidad y no faltaban órdenes que los expulsaban de su seno. Los reos para tratar de aminorar sus culpas y obtener menores penas, trataban de descalificar a los testigos y señalaban que las acciones o dichos deshonestos los tuvieron fuera del sacramento de la confesión y sin ninguna relación con él. Sin embargo, el Tribunal de Lima, siguiendo las instrucciones de Ia Suprema y los breves pontifícios, tenderá a rechazar esos argumentos, sobre todo el que se refería al 
momento y circunstancias en que se cometía el delito. Con los testigos en cambio se tuvo un criterio menos rígido, aceptándose muchas veces las tachas, en la medida que se trataba de pocas testificaciones, de mujeres con fama de deshonestas o indígenas. Por lo general, el reo no era absuelto, pero se le daba una sanción menor.

Todo análisis cuantitativo y valorativo que se haga con respecto a este delito no puede perder nunca de vista que el número de miembros del clero involucrados en él, fue muy bajo en relación con el total de eclesiásticos existente en el distrito de esta Inquisición, aun si se considera que un porcentaje importante de denuncias no se transformaron en procesos. Ahora bien, en el Tribunal de Lima se distinguen tres fases en la represión de este delito. La primera, que se extiende hasta 1615 , es la que concentra el mayor número de causas detectadas. La segunda fase que va hasta 1735 es de muy poca actividad, al punto que en sus primeros 20 años prácticamente no se procesa a nadie. La razón de ello está en que el Tribunal se encuentra absorbido por la represión a los judaizantes. La tercera fase llega hasta la extinción del Tribunal en 1820 y en ella se aprecia una reactivación de la labor represiva en torno al delito que nos preocupa, aunque el número de los encausados es muy inferior al de la primera etapa. Con todo, en comparación con los otros delitos, en esta última fase la solicitación pasará a ser el delito que concentra el porcentaje más importante de la actividad represiva del Tribunal. Este comportamiento guarda relación con lo que acontece en la península, donde se dan unas fases bastante parecidas, salvo en un cierto período del siglo XVII. Pero, en lo referente a la significación que tiene el delito con respecto al conjunto de la actividad represiva, sí se aprecia una diferencia más o menos importante entre los tribunales de Toledo y Cuenca y el de Lima, pues para éste representa alrededor del 7 por ciento, lo que implica una diferencia con los otros superior a los dos puntos porcentuales. No obstante ese hecho, para el Tribunal de Lima la solicitación fue bastante menos significativa que otros delitos, como los de bigamia, la hechicería, el judaísmo y las proposiciones, cada uno de los cuales implicaba más del 13 por ciento de su actividad.

El solicitante medio del distrito del Tribunal de Lima era un clérigo regular, preferentemente de la orden de San Francisco o de la Merced, cercano a los 40 años, bastante inculto y dedicado en su mayoría a cumplir funciones de doctrinero en pueblos de indios. Las víctimas, a su vez, correspondían en un alto porcentaje a mujeres indígenas, aunque también habían bastantes españolas y mestizas, pertenecientes casi siempre a los sectores sociales inferiores. Desde el punto de vista del estado civil, no existía mayor diferencias en cuanto al número entre solteras y casadas.

Missionalia Hispanica

Hispania Sacra 48 (1996) 
La perpetración de este delito tan especial, que implicaba la utilización de la penitencia como medio, se explica entre otros factores por las especiales características que revistió dicho sacramento en esa época. De hecho tendió a centrarse en los pecados contra el sexto y el noveno mandamiento. Por cierto, que esa peculiaridad alcanzaba una dimensión especial en un contexto en el que el discurso sobre materias sexuales no formaba parte de la cotidianeidad y la mujer era vista, por ciertos sectores eclesiásticos, como la encarnación del pecado de lujuria. Si a eso se agrega la existencia de un porcentaje importante de clérigos sin vocación y bastante ignorantes, tenemos la mayoría de los elementos que hacen inteligible un fenómeno como el analizado. Solo falta el escenario, que por lo general conresponde a una iglesia, inmersa en la penumbra y la cual hay capillas, sacristías y confesonarios de grandes dimensiones, que aíslan del resto de los fieles al sacerdote y la penitente, quienes muy juntos y en muchos casos sin nada que los separe, dialogan entre otros temas sobre aspectos de la vida íntima de ella.

Hay un último punto, él se refiere al alto porcentaje en que los solicitantes lograban consumar el objetivo final de su acción. Esto nos hace presumir un grado relativamente amplio de liberalidad sexual en los sectores inferiores de la sociedad, pues a ellos pertenecían la inmensa mayoría de las solicitadas, cuyo número era bastante elevado y bien podría constituir una muestra de conductas sociales más generales. Pero, lo anterior no debe hacer perder de vista la influencia que pudo tener en ese comportamiento la significación y poder que representaba la figura del sacerdote. Quién además recurrirá a los argumentos "religiosos", a los halagos, a las promesas e incluso a la violencia. En ese sentido, la solicitación en si misma, sin considerar los actos de fuerza que se pudieran cometer, implicaba violentar sicológicamente a la mujer en un alto grado. Eran muchísimas las penitentes que salían indignadas y escandalizadas por las proposiciones de que eran objeto en un momento y circunstancias tan especiales y que resultaban tan opuestos a lo que esperaban. Como señalaba el papa Gregorio XV en su bula de 1622 , en vez de medicina recibían veneno. 


\section{ÍNDICE GENERAL DEL TOMO 48}

Págs.

\section{IMAGEN Y REPRESENTACIÓN DE LOS OTROS}

MigUel-ÁNGEl LADERo QUESADA, La "decadencia" española como argumento historiográfico

JESÚs GÓMEZ, "El Diálogo del viejo y del mancebo" (1544) de Juan de Jarava, un caso de traducción encubierta

José Ramón Magdalena Nom de DÉu y JOSEPH ShatzMILler, De Venecia a Famagusta (Viaje de'Eliyahu da Pesaro-J563)

FLORENCIO HUBENAK, Historia Política y profecía: Roma y los grandes inperios antiguos a la luz de las predicciones del profeta Daniel

DE HISPANIA VISIGODA

JUAN José LARREA, El obispado de Pamplona en época visigoda

RAfael Barroso CABrera y Jorge Morin DE Pablos, La ciudad de Arcávica y la fundación del monasterio Servitano

\section{MISSIONALIA HISPANICA}

JosÉ ANTONIO BENITO RODRIGUEZ, La modélica gestión del contador de cruzada de Lima Gonzalo de la Maza .

JoSÉ ANDRÉs-GALLEGO, Esclavos de temporalidades (El Tucumán, 1768): posibilidad de una fuente documental .

JoSEP-IGNASI SARANYANA, Medio siglo de la "Revista Eclesiástica Brasileira" (REB)

BONIFACIO PORRES ALONSO, Los hospitales trinitarios de Argel y Túnez ..... TEODORO HAMPE MARTÍNEZ, El proceso de canonización de Santa Rosa (nuevas luces sobre la identidad criolla en el Perú colonial)

Rene Millar Carvacho, El delito de solicitación en el Santo Oficio de Lima 


\section{DE LA IGLESIA ANDALUZA}

José Manuel Cuenca TORIBIO, Ortodoxia y heterodoxia en la Andalicia ochocentista ..................................................................................

JoSÉ GARCIA-CUEVAS VENTURA, El cabildo catedralicio y el episcopado cordobés, del Antiguo al Nuevo Régimen (1789-1833).

ARTURO MORGADO, La Iglesia gaditana ante la crisis del Antiguo Régimen (1800-1833)

José Chamizo de la Rubia, Fray Félix María de Arriete y Llano, I864I879 (I)

\section{LA ENCRUCLJADA CONTEMPORÁNEA}

LUIS DE LLERA, /l decadentismo spagnolo fra letteratura e crisi modernista

José Chamizo de la Rubia, Fray Félix María de Arriete y Llano. 1864$1879(I)$

\section{PERSONALIDAD INTERNACIONAL DE LOS PAPAS}

JOSÉ ANDRÉS-GALLEGO, 1767: por qué los jesuitas

MAR MARCOS, Representaciones visuales del poder en época tardoantigua: La imagen de la emperatriz cristiana

SILVIA ACERBI, La societá ecclesiastica nell'Italia del VI secolo: clericalis ordo e scrinia apostolica attraveso l'Epistolario di papa Gregorio Magno

Glauco Maria Cantarella, Per un riesame della legazione papale in Spagna nell $/ / 12$

MARTÍN ALVIRA CABRER, El Venerable Arnaldo Amalarico (h. 1/96-1225): idea y realidad de un cisterciense entre dos cruzadas

M. ${ }^{\circ}$ LuZ Mandigorra Llavata, Acta Romanorum Pontificum in Archivo Diputationis Valentiae asservata

RESEÑAS

RESEÑAS 


\section{COLABORAN EN ESTE NÚMERO}

\author{
SILVIA ACERBI \\ Universidad de Cantabria. \\ MARTín Alvira CABrer \\ Universidad Complutense. \\ Madrid. \\ JOSE ANDRÉS-GALLEGO \\ Hispania Sacra. \\ JUAN JOSÉ BARROSO CABRERA \\ JOSÉ ANTONIO BENITO RODRÍGUEZ \\ Glauco Maria Cantarella \\ Universidad de Bolonia. \\ José MANuel CuenCA TORIBIO \\ Universidad de Córdoba. \\ José ChaMizo de LA RUBIA \\ Universidad de Cádiz. \\ JosÉ GRACÍA-CuEvas VENTURA \\ Universidad de Córdoba.

\section{JESÚS GÓMEZ} \\ Universidad Autónoma. \\ Madrid, \\ Teodoro Hampe Martínez \\ Pontificia Universidad Católica del Perú. \\ FLORENCIO HUBEÑÁK \\ Universidad Católica Argentina. \\ Buenos Aires.
}

Miguel Ángel, Ladero Quesada

Universidad Complutense.

Madrid.

JUAN JOSÉ LARREA

Universidad del País Vasco.

Vitoria.

JoSÉ RAMÓN MAGDALENA NOM DE DÉU

Universidad Central.

Barcelona.

M. ${ }^{2}$ Luz Mandingorra Llavata

Universidad de Valencia.

RenÉ Millar CaRvacho

Academia Chilena de la Historia.

ARTURO MORGADO

Universidad de Cádiz.

JORGE MORIN DE PABLOS

BONIFACIO PORRES ALONSO

MAR MarCos

Universidad de Cantabria.

JOSEP-IGNASI SARANYANA

Universidad de Navarra.

Pamplona.

FranCisCo José SANCHIS MoRENO.

Archivo de la Diputación de Valencia. 